\title{
The freshwater shrimp Gammarus lacustris (Malacostraca, Amphipoda) in lakes on the Hardangervidda mountain plateau, southern Norway: distribution and environmental requirements
}

\author{
Tore Qvenild', Trygve Hesthagen ${ }^{2}$ and Arne Fjellheim ${ }^{3}$
}

Qvenild T, Hesthagen T and Fjellheim A. 2020. The freshwater shrimp Gammarus lacustris (Malacostraca, Amphipoda) in lakes on the Hardangervidda mountain plateau, southern Norway: distribution and environmental requirements. Fauna norvegica 40: 1-21.

\begin{abstract}
The distribution of the amphipod Gammarus lacustris on the Hardangervidda mountain plateau was mapped by screening published data from 245 lakes in 11 and 16 catchments in western and central/eastern areas, respectively. These data are primarily based on stomach analyses of brown trout Salmo trutta. In central/eastern areas, G. lacustris was recorded in $79 \%$ of all the lakes examined, while there are only two former records (4\%) in the western area. The distribution pattern of G. lacustris on Hardangervidda appears to be related to environmental conditions. The apparent absence of G. lacustris in the western area may be explained by a combined effect of cold water due to higher deposits of snow and water with low ionic strength as a consequence of its bedrock of Precambrian gneisses and granites with little or no moraine cover. However, lakes in central/eastern areas sustain G. lacustris in spite of dilute water, as $G$. lacustris has been recorded in 89 lakes of which $28 \%$ had calcium concentration $<1.0 \mathrm{mg} \mathrm{L}^{-1}$, eight of them with $\mathrm{pH}<6.0$. The lower lethal threshold for calcium concentration seems to be $\sim 0.5 \mathrm{mg} \mathrm{L}^{-1}$. Gammarus lacustris was found in lakes at altitudes of 832 to $1396 \mathrm{~m}$ a.s.l. Furthermore, their occurrence increased significantly with lake size, being $69 \%$ in lakes $<1.0 \mathrm{~km}^{2}$ and $97 \%$ in larger lakes. The number of refugia with better water quality is likely to increase with lake size. Gammarus lacustris is highly searched for as prey by all size groups of brown trout $(15-45 \mathrm{~cm})$. Access to proximity refugia that reduce predation pressure from fish may also increase with lake size. Climate changes are now in progress in this mountain area, and detailed mapping of G. lacustris is important in order to trace future range changes.
\end{abstract}

doi: 10.5324/fn.v40i0.3101. Received: 2019-07-02. Accepted: 2020-01-21. Published online: 2020-03-16. ISSN: 1891-5396 (electronic).

Keywords: distribution, Hardangervidda, fish predation, environmental conditions, climate change

1. County Governor of Innlandet, Statens hus, Parkgata 36, NO-2317 Hamar, Norway

2. Norwegian Institute for Nature Research (NINA), PO box 5685, Torgarden, NO-7485 Trondheim

3. NORCE Norwegian Research Centre AS, Nygårdsgaten 112, NO-5008 Bergen, Norway

Corresponding author: Tore Qvenild

E-mail: fmhetq@fylkesmannen.no

\section{INTRODUCTION}

The amphipod Gammarus lacustris G.O. Sars, 1863 is a typical benthic littoral species, preferring shallow vegetated areas down to five $\mathrm{m}$ (Dahl 1915, 1917). Gammarus lacustris is an omnivore grazing on plant debris both from within the lakes and from allochthonous material, and to some extent, also preying on animals, including conspecifics (Dahl 1915; Wilhelm \& Schindler 2000; Rognerud et al. 2003). Thus, G. lacustris plays an important ecosystem role in linking terrestrial detritus and periphytic algal production to higher trophic organisms such as fish. In the old days, G. lacustris was a problem for the fisheries due to its attraction to and destroying the fishing nets made of cotton, linen or hemp (Dahl 1915). Seen in retrospection, these materials might have been optimal substrates for periphytic algae.
The Hardangervidda mountain plateau is the largest peneplain (eroded plain) in Europe (Anonymous 1974). Gammarus lacustris was early stated as a staple food item for brown trout Salmo trutta Linnaeus, 1758 in lakes on this mountain plateau (Huitfeldt-Kaas 1911; Dahl 1917; Sømme 1941). Here, the brown trout is the only species in most lakes (Qvenild \& Hesthagen 2019). They are rated among the best brown trout lakes in Norway, hosting large fish of high quality (Sømme 1941). A rich supply of crustacean food items is regarded as the main reason for prolonged growth of brown trout to sizes of one to three $\mathrm{kg}$ and even more (Huitfeldt-Kaas 1911; Dahl 1917; Sømme 1941). The largest brown trout properly reported on Hardangervidda was $81 \mathrm{~cm}$ in length and with a weight of $7.6 \mathrm{~kg}$ (Borgstrøm 2016). However, specimens greater than this are known; e.g. $11 \mathrm{~kg}(\mathrm{Qvenild}$ 2004). Gammarus lacustris is a conspicuous large $(\sim 1-2 \mathrm{~cm})$ food item, often occurring with a grey-brown body that is easy to observe. 
Thus, it is familiar to local fishermen and has a variety of local names such as "marflo, matflo, grunnåte, nettskjær, etc." (Dahl 1915). The easy access to crustacean food items is also reflected in the carotenoid coloured flesh of brown trout, which makes them highly valued as human food.

Gammarus lacustris has a circumpolar distribution and is widely distributed in Norwegian lakes, indicating that it is well adapted to a wide range of environmental conditions (Økland \& Økland 2007). The species is highly sensitive to acid water and it is frequently used as an indicator species, being not present at $\mathrm{pH}$ values $<5.5$ (Fjellheim \& Raddum 1990). It is not usually found in lakes with $\mathrm{pH}<6.0$ (Økland $\&$ Økland 2007). Furthermore, calcium is essential to all crustaceans and low levels may also affect their survival and pattern of distribution (Rukke 2002; Cairns \& Yan 2009). In their review paper, Cairns \& Yan set the lower lethal threshold of calcium for gammarids slightly above $1.0 \mathrm{mg} \mathrm{L}^{-1}$, although lower levels at higher $\mathrm{pH}$ values have been recorded (Økland \& Økland 2007). On Hardangervidda, there are many lakes with waters low in calcium $\left(<1.0 \mathrm{mg} \mathrm{L}^{-1}\right)$ and with corresponding $\mathrm{pH}<6.0$ (Skjelkvåle \& Henriksen 1998). Even though gammarid studies suggest that crustacean populations may be somewhat adaptable to existence in calcium-poor environments (Cairns \& Yan 2009), we hypothesize that G. lacustris in such lakes is living near to its lethal thresholds. To the extent that it is present in such dilute waters, additional stressors such as low thermal input and fish predation may be detrimental.

In mountain lakes in southern Norway, G. lacustris seem to have a preference for the temperature range of 10 to $14^{\circ} \mathrm{C}$ in summer (Økland \& Økland 2007). Even though it appears to tolerate a wide range of temperatures, a minimum thermal input is needed to complete the life cycle. This is reflected in the phenotypic plasticity in its reproductive traits (Dahl 1915; Bjerknes 1974; Wilhelm \& Schindler 2000; Økland \& Økland 2007; Østbye et al. 2018). Both altitude and snow deposition provide a variety of temperature regimes in lakes on Hardangervidda (Qvenild \& Hesthagen 2019), which is likely to affect the distribution and abundance of G. lacustris (Rukke 2002; Økland \& Økland 2007).

With its perennial life cycle, G. lacustris is a permanently available food resource for fish in alpine lakes (Dahl 1930). However, heavy fish predation may affect both abundance and demographic structure, either temporarily or permanently (Dahl 1915, 1917; Sømme 1941; Aass 1969; Wilhelm \& Schindler 2000; Museth \& Borgstrøm 2010; Qvenild \& Rognerud 2018). As fish may well exert high predation pressure on G. lacustris, access to proximity species refugia could be crucial in optimising its survival at a local level.

The distribution pattern of $G$. lacustris on Hardangervidda appears to be skewed, with most of the known localities being in the central and eastern areas (Anonymous 1974). However, their distribution has only been partially mapped. The main goal of this study was to compile for new records in the pertinent literature from this mountain plateau. To analyse the distribution pattern, we separated the area into a western and central/eastern region, due to differences in their geology, water quality and snow deposition. Our key question is whether the distribution pattern of G. lacustris on Hardangervidda can be explained by these environmental conditions.

\section{MATERIAL AND METHODS}

\section{Study area}

The Hardangervidda landscape is characterized by barren, treeless moorland interrupted by numerous pools, lakes, rivers and streams.
The plateau covers an area of about $9800 \mathrm{~km}^{2}$, of which the most remote parts account for about $8000 \mathrm{~km}^{2}$ (Anonymous 1974). Our study area included 27 catchments (Table 1), comprising $6569 \mathrm{~km}^{2}$ (Qvenild \& Hesthagen 2019). The extent of these catchments was calculated using the NEVINA procedure (NVE Atlas, nve.no). In these catchments, 930 named lakes covering $656 \mathrm{~km}^{2}$ have been identified (NVE Atlas, nve.no). They are located at altitudes between 414 to $1527 \mathrm{~m}$ a.s.l. and range in size from 0.004 to $78.77 \mathrm{~km}^{2}$. In addition, there are approximately 11,600 small unnamed lakes and ponds ranging in size between 0.0006 and $0.7035 \mathrm{~km}^{2}$ with a total area of $157 \mathrm{~km}^{2}$ (Qvenild \& Hesthagen 2019). Of the named lakes, $85 \%$ are situated at altitudes of 1100 to $1399 \mathrm{~m}$ a.s.l., while 11 and $4 \%$ are located at lower and higher altitudes, respectively. Most of the 36 natural lakes with bathymetric maps on Hardangervidda have a mean depth of $<10$ m (Qvenild \& Hesthagen 2019). The 930 named lakes include 27 reservoirs for hydropower production, ranging in size from 0.48 to $78.77 \mathrm{~km}^{2}$ (Appendix 1). The annual water level fluctuation ranged from 0.5 to $91.9 \mathrm{~m}$, most of the lakes being regulated $>10 \mathrm{~m}$ (77\%) and 58\% >20 m (NVE Atlas, nve.no).

The western area of Hardangervidda is dominated by rocky terrain and expanses of bare rock with thin or no moraine-covered bedrock of Precambrian gneisses and granites with sparse or no vegetation. The catchments in the eastern area also cover gneisses and granites, but due to deeper layers of the moraine, they are usually more vegetated. In the central part of Hardangervidda, the bedrock of Cambro-Silurian sedimentary origin provides a richer soil.

The water chemistry in the lakes closely reflects the local bedrock geology (Skjelkvåle \& Henriksen 1998). The Hardangervidda National Park covers an area of $3422 \mathrm{~km}^{2}$ in the most remote part of the plateau. Here, a detailed water quality monitoring programme was conducted in 102 lakes in 1997 (Skjelkvåle \& Henriksen 1998). The water chemistry varied greatly, from lakes with very dilute water, to lakes with high ionic strength (conductivity range $0.53-3.63 \mathrm{mS} \mathrm{m}^{-1}$ ). The calcium concentration and $\mathrm{pH}$ ranged between $0.33-5.73 \mathrm{mg} \mathrm{L}^{-1}$ and $5.35-7.28$, respectively. The total organic carbon content (TOC) is low, as $85 \%$ of the lakes had $<2.0 \mathrm{mg} \mathrm{C} \mathrm{L}^{-1}$. Lakes in the western area are particularly low in TOC with a mean of $\sim 0.3 \mathrm{mg} \mathrm{C} \mathrm{L}^{-1}$.

There is a highly seasonal variation in both $\mathrm{pH}$ and calcium in lakes on Hardangervidda. The lowest $\mathrm{pH}$ and the highest values of calcium are usually recorded in the spring (Fjellheim et al. 2002, 2007, 2018). In fact, in small lakes and brooks, the calcium concentration in spring may be more than twice the minimum value later in the season. In bigger lakes, these variations follow the same pattern, but to a much smaller extent. We assume that the minimum ambient calcium value through the summer and autumn is the most critical for G. lacustris when the neonates develop into adults. Hence, we only used data from this period when assessing the occurrence of G. lacustris. We have summer-autumn values for calcium concentration with corresponding $\mathrm{pH}$ values from 219 natural lakes (Appendix 1).

The climatic conditions on Hardangervidda are also highly variable (Qvenild \& Hesthagen 2019). The winter and summer precipitation are computed using the NEVINA procedure (NVE Atlas, nve.no) as mean values for the normal period 1961-1990 (Table 1). The snow deposition (October-April) differs substantially in a west to east gradient with an almost four-fold decrease from $1151 \mathrm{~mm}$ in Austdølo/ Ljoso catchment to $292 \mathrm{~mm}$ in Uvdalselvi catchment. The mean summer precipitation (May-September) in these two catchments varied less; being 614 and $332 \mathrm{~mm}$, respectively. The mean winter and summer temperatures are computed similarly (Table 1). 
Table I. Number of lakes examined for Gammarus lacustris in the 27 catchments (no 1-20) studied on Hardangervidda $\left(6569 \mathrm{~km}^{2}\right)$ of which 20 and $80 \%$ are in the western $(\mathrm{W})$ or central/eastern $(\mathrm{C} / \mathrm{E})$ region, respectively. The mean winter and summer precipitation (mm) and winter and summer temperatures $\left({ }^{\circ} \mathrm{C}\right)$, are given for the normal period 1961-1990 computed by the NEVINA procedure (NVE Atlas, nve.no). Of the 245 lakes properly examined for Gammarus lacustris, $65 \%$ produced positive records. Many of the lakes are repeatedly investigated given with a factor in the last column $(\mathrm{RE}=$ number of examinations/number of examined lakes).

\begin{tabular}{|c|c|c|c|c|c|c|c|c|c|c|c|c|c|c|c|}
\hline ž & 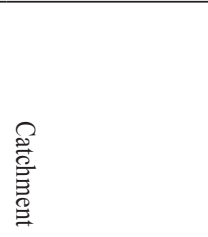 & 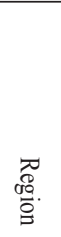 & 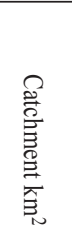 & 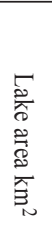 & 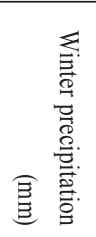 & 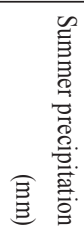 & 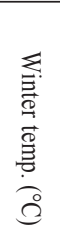 & 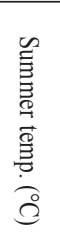 & 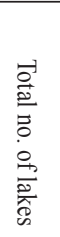 & 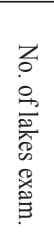 & 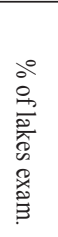 & 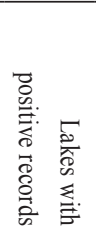 & 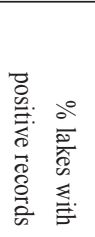 & 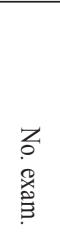 & 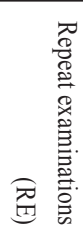 \\
\hline 1 & Austdøla & W & 121 & 13 & 1000 & 594 & -4.2 & 4.3 & 22 & 10 & 45 & 0 & 0 & 16 & 1.60 \\
\hline 2 & Sima & W & 121 & 4 & 832 & 504 & -5.1 & 3.1 & 14 & 1 & 7 & 0 & 0 & 2 & 2.00 \\
\hline $3 \mathrm{~A}$ & Isdølo & $\mathrm{C} / \mathrm{E}$ & 55 & 2 & 725 & 434 & -4.5 & 4.1 & 6 & 1 & 17 & 1 & 100 & 2 & 2.00 \\
\hline $3 \mathrm{~B}$ & Leiro & $\mathrm{C} / \mathrm{E}$ & 211 & 18 & 571 & 406 & -6.1 & 3.7 & 22 & 8 & 36 & 1 & 13 & 12 & 1.50 \\
\hline $3 \mathrm{C}$ & Svinto & $\mathrm{C} / \mathrm{E}$ & 35 & 0 & 497 & 356 & -7.9 & 4.3 & 2 & 1 & 50 & 1 & 100 & 2 & 2.00 \\
\hline 4 & Bjoreio & $\mathrm{C} / \mathrm{E}$ & 150 & 9 & 527 & 356 & -6.9 & 4.2 & 14 & 3 & 21 & 3 & 100 & 15 & 5.00 \\
\hline 5 & Veig & $\mathrm{C} / \mathrm{E}$ & 395 & 10 & 669 & 375 & -5.9 & 4.4 & 37 & 20 & 54 & 12 & 60 & 37 & 1.85 \\
\hline $6 \mathrm{~A}$ & Erdalsvassdraget & $\mathrm{C} / \mathrm{E}$ & 63 & 1 & 809 & 387 & -1.8 & 6.0 & 2 & 2 & 100 & 2 & 100 & 5 & 2.50 \\
\hline $6 \mathrm{~B}$ & Bjotveitelvi & W & 16 & 1 & 944 & 447 & -1.4 & 6.4 & 2 & 1 & 50 & 1 & 100 & 4 & 4.00 \\
\hline $7 \mathrm{~A}$ & Kinso & $\mathrm{C} / \mathrm{E}$ & 210 & 14 & 900 & 435 & -4.0 & 4.5 & 31 & 15 & 48 & 7 & 47 & 35 & 2.33 \\
\hline $7 \mathrm{~B}$ & Vivippo & W & 39 & 1 & 919 & 423 & -1.6 & 5.7 & 4 & 3 & 75 & 0 & 0 & 5 & 1.67 \\
\hline 8 & Opo & W & 63 & 4 & 984 & 460 & -2.0 & 5.2 & 10 & 4 & 40 & 0 & 0 & 4 & 1.00 \\
\hline $9 \mathrm{~A}$ & Espeelvi & W & 9 & 0 & 938 & 489 & -2.7 & 5.1 & 1 & 1 & 100 & 0 & 0 & 1 & 1.00 \\
\hline $9 \mathrm{~B}$ & Vendo & W & 29 & 4 & 1013 & 518 & -3.3 & 4.0 & 2 & 1 & 50 & 0 & 0 & 2 & 2.00 \\
\hline 10 & Tysso & W & 381 & 44 & 1062 & 590 & -4.2 & 4.1 & 46 & 20 & 43 & 0 & 0 & 53 & 2.65 \\
\hline 11 & Austdølo/Ljoso & W & 120 & 9 & 1151 & 614 & -3.2 & 4.5 & 13 & 3 & 23 & 0 & 0 & 3 & 1.00 \\
\hline 12 & Suldalsvassdraget & W & 217 & 10 & 984 & 586 & -5.3 & 3.9 & 7 & 1 & 14 & 0 & 0 & 2 & 2.00 \\
\hline 13 & Bora & W & 171 & 18 & 742 & 442 & -5.9 & 4.5 & 34 & 2 & 6 & 1 & 50 & 6 & 3.00 \\
\hline 14 & Songa & $\mathrm{C} / \mathrm{E}$ & 379 & 42 & 582 & 400 & -5.8 & 4.8 & 44 & 11 & 25 & 6 & 55 & 25 & 2.27 \\
\hline 15 & Kvenna & $\mathrm{C} / \mathrm{E}$ & 828 & 61 & 571 & 390 & -7.8 & 4.5 & 99 & 39 & 39 & 30 & 77 & 146 & 3.74 \\
\hline 16 & Møsvatn & $\mathrm{C} / \mathrm{E}$ & 525 & 104 & 434 & 380 & -6.1 & 4.7 & 103 & 5 & 5 & 3 & 60 & 6 & 1.20 \\
\hline 17 & Mår/ Gøyst & $\mathrm{C} / \mathrm{E}$ & 732 & 102 & 304 & 339 & -6.7 & 4.8 & 156 & 13 & 8 & 13 & 100 & 28 & 2.15 \\
\hline $18 \mathrm{~A}$ & Uvdalselvi & $\mathrm{C} / \mathrm{E}$ & 196 & 10 & 292 & 332 & -6.6 & 5.1 & 39 & 5 & 13 & 5 & 100 & 10 & 2.00 \\
\hline $18 \mathrm{~B}$ & Ølmosåi & $\mathrm{C} / \mathrm{E}$ & 188 & 22 & 314 & 355 & -6.8 & 4.8 & 37 & 5 & 14 & 4 & 80 & 11 & 2.20 \\
\hline $19 \mathrm{~A}$ & Lågen & $\mathrm{C} / \mathrm{E}$ & 1179 & 134 & 511 & 344 & -8.1 & 4.7 & 154 & 60 & 39 & 59 & 98 & 233 & 3.88 \\
\hline 19B & Ufysja & $\mathrm{C} / \mathrm{E}$ & 61 & 3 & 322 & 323 & -5.8 & 5.0 & 10 & 5 & 50 & 5 & 100 & 15 & 3.00 \\
\hline \multirow[t]{2}{*}{20} & Ørteråni & $\mathrm{C} / \mathrm{E}$ & 76 & 16 & 404 & 339 & -7.4 & 4.6 & 19 & 5 & 26 & 5 & 100 & 30 & 6.00 \\
\hline & & & 6569 & 656 & & & & & 930 & 245 & 26 & 159 & 65 & 710 & 2.90 \\
\hline
\end{tabular}

\section{Mapping the presence of Gammarus lacustris}

Data regarding the presence or absence of $G$. lacustris were screened from relevant literature, such as technical reports and scientific papers (Appendix 1). The data covered 198 named lakes in 16 catchments in central/eastern areas, and 47 lakes in 11 catchments in western areas including 10 and 15 reservoirs, in the respective areas. The study lakes are located at altitudes between 464 to $1396 \mathrm{~m}$ a.s.l. and range in size from 0.02 to $78.77 \mathrm{~km}^{2}$. In most of the literature, the occurrence of $G$. lacustris is based on brown trout stomach analyses. In more detailed investigations, the occurrence of different food items is given as volume $\%$ of individual fish. However, in many of the reports, only a note may be given for a positive finding of $G$. lacustris. Other methods used to detect G. lacustris on Hardangervidda have included Ekman bottom sampler (Dahl 1917; Amundsen 1976), Petersen sampler
(Amundsen 1976), plankton sieves (Halvorsen 1973), benthic littoral kick samples (Walseng et al. 1994, 1996; Fjellheim et al. 2007) and artificial substrate (jute bags) (Fjellheim et al. 2007).

Brown trout is the most common fish species in lakes and rivers on Hardangervidda. In 3.1\% of the named lakes ( $\mathrm{N}=29)$, Arctic char Salvelinus alpinus (Linnaeus, 1758) also occur, mainly due to $20^{\text {th }}$-century stockings (Appendix 1). Furthermore, the Eurasian minnow Phoxinus phoxinus (Linnaeus, 1758) has been introduced into 42 named lakes (4.5\%) since the 1970 s.

\section{Statistical analyses}

Statistical analyses of the type one-way analysis of variance (ANOVA) and nominal logistic regression were performed with SPSS (IBM Corp. 2017. IBM SPSS Statistics for Windows, Version 25.0. Armonk, 


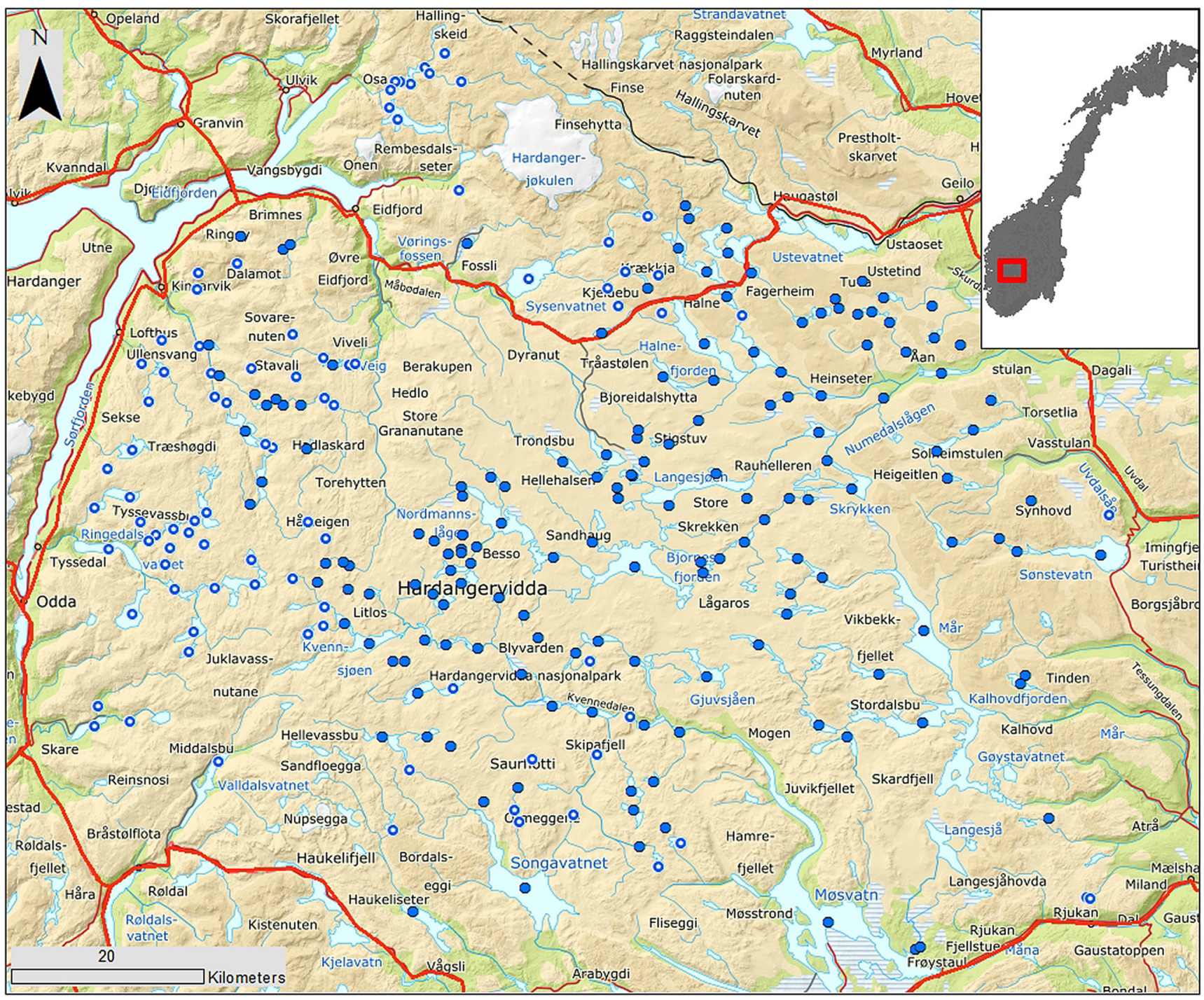

Figure I. Lakes surveyed for the presence of Gammarus lacustris on Hardangervidda. Lakes with positive and negative findings are shown by filled and open dots, respectively. Details of the localities are given in Appendix 1. The Norwegian Mapping Authority CC BY 4.0.

Table 2. Number of natural lakes with Gammarus lacustris at different altitude intervals in 16 catchments located in central and eastern areas on Hardangervidda.

\begin{tabular}{|c|c|c|c|c|}
\hline 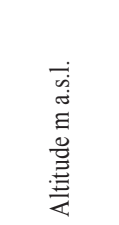 & 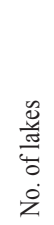 & 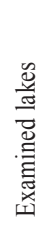 & 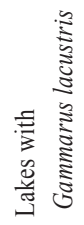 & 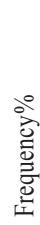 \\
\hline$<900$ & 4 & 4 & 3 & 75 \\
\hline 900-999 & 15 & 6 & 5 & 83 \\
\hline $1000-1099$ & 59 & 19 & 9 & 47 \\
\hline $1100-1199$ & 264 & 72 & 56 & 78 \\
\hline $1200-1299$ & 270 & 60 & 50 & 83 \\
\hline $1300-1399$ & 141 & 27 & 24 & 89 \\
\hline \multirow[t]{2}{*}{$\geq 1400$} & 12 & 0 & & \\
\hline & 765 & 188 & 147 & 78 \\
\hline
\end{tabular}

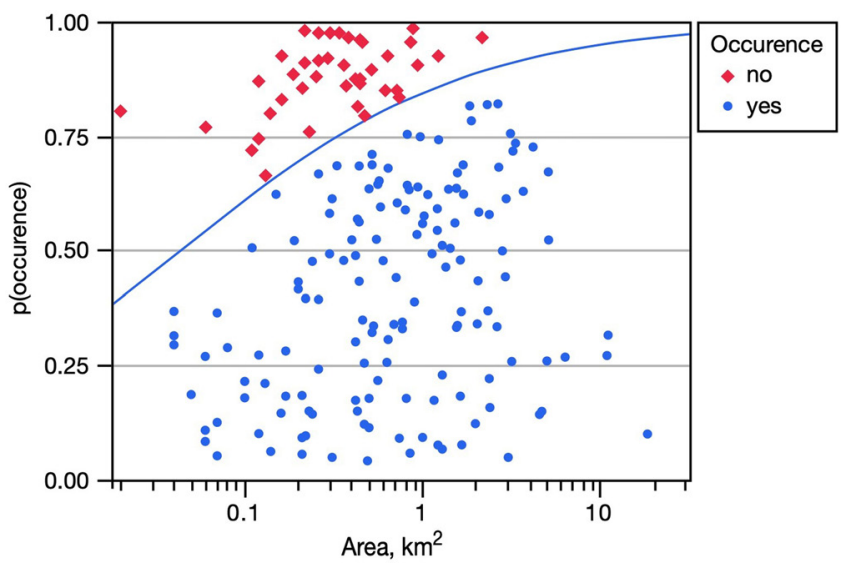

Figure 2. Logistic regression curve showing the probability of the occurrence of Gammarus lacustris on Hardangervidda as a function of lake area. Of the 188 lakes studied, Gammarus lacustris was found in $97 \%$ of the 62 lakes $\geq 1.0 \mathrm{~km}^{2}$, while the species was found in only $67 \%$ of 126 lakes $<1.0 \mathrm{~km}^{2}$. 
Table 3. Water quality in terms of $\mathrm{pH}$ and calcium concentration in 219 lakes on Hardangervidda with 191 and 28 lakes in the central/eastern (C/E) and western (W) areas, respectively. For the central/eastern area, the water quality is given for lakes with and without records of Gammarus lacustris, respectivelly.

\begin{tabular}{|c|c|c|c|c|c|c|c|}
\hline Region & & No. lakes & $\mathrm{pH}$ range & $\begin{array}{c}\text { No. of lakes } \\
\mathrm{pH}<6.0\end{array}$ & $\begin{array}{c}\text { Ca mean } \pm \text { SD } \\
\mathrm{mg} \mathrm{L}^{-1}\end{array}$ & $\begin{array}{c}\text { Ca range } \\
\mathrm{mg} \mathrm{L}^{-1}\end{array}$ & $\begin{array}{l}\text { No. of lakes with Ca } \\
\quad<1.0 \mathrm{mg} \mathrm{L}^{-1}\end{array}$ \\
\hline $\mathrm{C} / \mathrm{E}$ & All lakes & 191 & $5.19-7.28$ & $20(10 \%)$ & $1.63 \pm 1.14$ & $0.28-5.73$ & $70(37 \%)$ \\
\hline $\mathrm{C} / \mathrm{E}$ & Lakes with G. lacustris & 89 & $5.49-7.26$ & $8(9 \%)$ & $1.84 \pm 1.18$ & $0.28-5.54$ & $25(28 \%)$ \\
\hline $\mathrm{C} / \mathrm{E}$ & Lakes without G. lacustris & 102 & $5.19-7.28$ & $12(12 \%)$ & $1.45 \pm 1.08$ & $0.37-5.73$ & $45(44 \%)$ \\
\hline W & All lakes & 28 & $5.35-7.00$ & $6(21 \%)$ & $0.76 \pm 0.39$ & $0.32-1.68$ & $22(79 \%)$ \\
\hline $\mathrm{W}$ and $\mathrm{C} / \mathrm{E}$ & All lakes & 219 & $5.19-7.28$ & $26(12 \%)$ & $1.52 \pm 1.11$ & $0.28-5.73$ & $92(42 \%)$ \\
\hline
\end{tabular}

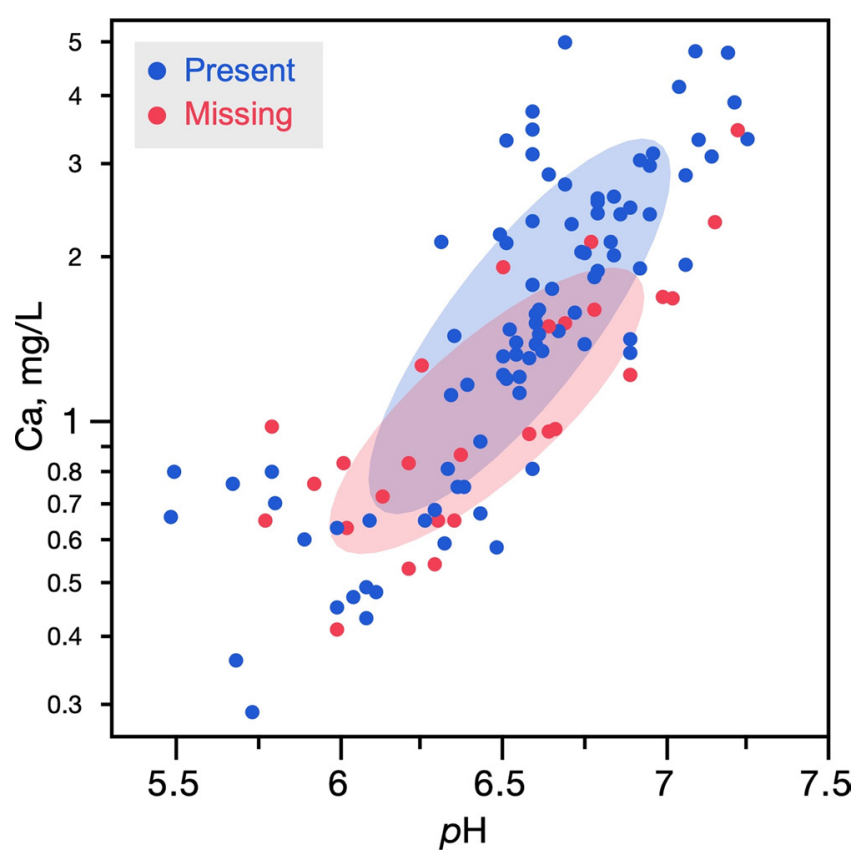

Figure 3. The bivariate distribution of $\mathrm{pH}$ and calcium (log-transformed) in water samples from the study lakes, grouped for lakes with or without Gammarus lacustris ( $\mathrm{N}=89$ and 27, respectively). The bivariate 50\% confidence ellipses are drawn for each group.

NY) and JMP (SAS Institute Inc. 2019. Version 14.3. Cary, NC), respectively. The logistic regression was used to model the probability of the occurrence of G. lacustris as a function of lake size, and the result is visualised with a cumulative logistic probability plot. This presents the regression curve giving the probability for occurrence as a function of lake size, and the markers for the data are drawn at their $x$-coordinate, with the $y$-position jittered randomly within the range corresponding to their response category. We also visualised the bivariate distributions of calcium concentrations and $\mathrm{pH}$ in the study lakes by a scatter plot with confidence ellipses drawn for the lake groups with and without $G$. lacustris. The density ellipsoids are computed from the bivariate normal distribution fit to the variables.

\section{RESULTS}

\section{Geographical distribution of Gammarus lacustris}

A total of 710 observations covering 245 lakes, of which 159 lakes $(65 \%)$ resulted in positive findings of G. lacustris (Figure 1, Table 1). Most of the records are from the 16 central and eastern catchments, being noted in $79 \%$ of the 188 natural lakes examined. From 47 lakes in the 11 western catchments, G. lacustris are reported from only two lakes (4\%). In Lake Bordalsvatn, which is now a reservoir (regulated $39.0 \mathrm{~m})$, G. lacustris was recorded before the impoundment, but never thereafter. In the other locality, Lake Vatnosetvatn, there is an old record of G. lacustris. This observation has proved to be difficult to verify and has not been replicated in later investigations.

Gammarus lacustris was recorded in $64 \%$ of the central and eastern lakes that were sampled once $(\mathrm{N}=80)$. This fraction increased to $76 \%$ and $96 \%$ with two sample repeats $(\mathrm{N}=37)$ and three or more sample repeats $(\mathrm{N}=71)$, respectively.

\section{Gammarus lacustris in reservoirs}

Our study area comprised 27 reservoirs for hydropower production, 25 of which were investigated for records of G. lacustris. The reservoirs were extensively studied after impoundment, but rarely before. In the central and eastern part of Hardangervidda, most of the reservoirs $(\mathrm{N}=10)$ were studied more than four times, and in six of them, G. lacustris still occur after many years of impoundment. Of these reservoirs, three are regulated less than six m (0.5-4.1 m) and three more than ten $\mathrm{m}$ (11.1-39.1 m). In the three reservoirs which are regulated less than six $\mathrm{m}, G$. lacustris still play an important part as food for the brown trout. The four remaining reservoirs without $G$. lacustris are regulated from 18.5 to $66.0 \mathrm{~m}$. In western areas, none of the 15 reservoirs produced positive findings of $G$. lacustris in recent years.

\section{The significance of altitude and lake size}

Data from the 188 natural lakes within the 16 catchments in the central and eastern areas of Hardangervidda were used to analyse the frequency of $G$. lacustris in relation to altitude and lake size. The lakes lie at altitudes from 832 to $1396 \mathrm{~m}$ a.s.l. The occurrence of $G$. lacustris is high with $75-89 \%$ in all 100-m intervals, except for the 1000-1099 m a.s.l. interval, where it was only $47 \%$ (Table 2). The highest located lake with G. lacustris was Lake Kolsnutgrysline situated at $1386 \mathrm{~m}$ a.s.l. The two lakes in the 11 western catchments with records of $G$. lacustris lie at altitudes of 869 and $891 \mathrm{~m}$ a.s.l., respectively.

The incidence of $G$. lacustris increased significantly with lake size as shown by the logistic regression: $\mathrm{p}$ (occurrence) $=(1+\exp$ $(1.380+2.026 \cdot \log \text { Area) })^{-1}$ (likelihood-ratio chi-square test $=12.65$ $\mathrm{p}<0.001$ ) (Figure 2). Of the 188 lakes examined, G. lacustris was found in $97 \%$ of the 62 lakes $\geq 1.0 \mathrm{~km}^{2}$, while the species was found in only $69 \%$ of the 126 lakes $<1.0 \mathrm{~km}^{2}$.

\section{Ambient water quality}

In this context, we have used calcium and concurrent $\mathrm{pH}$ values from 219 natural lakes (Appendix 1). Lakes in western and central/eastern 
areas differed significantly in calcium (ANOVA-test, $\mathrm{F}_{1,217}=15.92$ $\mathrm{p}<0.0001)$. The mean concentration of calcium in these two areas were $0.76 \pm 0.39(\mathrm{~N}=28)$ and $1.63 \pm 1.14(\mathrm{~N}=191) \mathrm{mg} \mathrm{L}^{-1}$, respectively. However, in both areas a large proportion of the lakes were low in calcium, as $79 \%(\mathrm{~N}=22)$ and $37 \%(\mathrm{~N}=70)$, respectively, had concentrations $<1.0 \mathrm{mg} \mathrm{L}^{-1}$ (Table 3). In both areas, the concurrent $\mathrm{pH}$ was also low, as respectively $21 \%(\mathrm{~N}=6)$ and $10 \%(\mathrm{~N}=20)$ of the lakes were $<6.0$.

Lakes in the central and eastern area with G. lacustris present, had significant higher concentrations of calcium than those with unknown status (19 examined lakes with negative records of $G$. lacustris and 27 lakes with only water quality analyses), with mean values of $1.84 \pm 1.18(\mathrm{~N}=89)$ and $1.45 \pm 1.08(\mathrm{~N}=102) \mathrm{mg} \mathrm{L}^{-1}$, respectively (ANOVA-test, $\mathrm{F}_{1,189}=4.65 \mathrm{p}<0.05$ ).

The tendency for higher calcium concentrations in lakes inhabited by G. lacustris is illustrated in Figure 3. Here, the confidence ellipses for the distributions of calcium and $\mathrm{pH}$ for the lakes with and without G. lacustris clearly show that the crustacean inhabit the more calcium rich lakes in our data set, whereas $\mathrm{pH}$ seems to be less associated to its occurrence. Analyses of variance showed that the geometric mean of calcium concentrations were significant higher in lakes with $G$. lacustris (1.48 $\mathrm{mg} \mathrm{L}^{-1}, 95 \%$ confidence interval: $1.29-1.70 \mathrm{mg} \mathrm{L}^{-1}$ ) than in lakes without $\left(1.03 \mathrm{mg} \mathrm{L}^{-1}, 95 \%\right.$ confidence interval: $0.80-1.32$ $\mathrm{mg} \mathrm{L}^{-1}$ ) (ANOVA-test, $\mathrm{F}_{1,114}=6.04 \mathrm{p}=0.013$ ). No such differences could be detected for $\mathrm{pH}\left(\mathrm{F}_{1,114}=1.33 \mathrm{p}=0.25\right)$.

\section{DISCUSSION}

\section{Distribution pattern of Gammarus lacustris on Hardangervidda}

The lakes on Hardangervidda are rated among the best brown trout lakes in Norway, and their relatively dense populations of G. lacustris are often mentioned as the main reason for prolonged growth and high quality of brown trout (Dahl 1915; Sømme 1941). Despite this, only a fragmentary mapping of this crustacean was available as recently as in the 1970s (Anonymous 1974). A large number of fishery investigations have been carried out since then, and in this study one of our main aims was to scan the pertinent literature in order to update the occurrence of the species. Gammarus lacustris is frequently found in fish stomachs, and thus an efficient method to map its occurrence in lakes on Hardangervidda. In fact, in most of the lakes examined, this is the only method used. However, other methods may be used simultaneously. In a study comprising 22 lakes, both bottom samplers (Ekman or Petersen) and fish stomachs were used, giving positive records of G. lacustris in 82 and $100 \%$ of the cases, respectively (Dahl 1917; Amundsen 1976). However, G. lacustris may be difficult to detect using conventional methods such as benthic littoral kick sampling, especially at low densities and/or patchy distribution (Walseng et al. 1994, 1996; Fjellheim et al. 2007). In a repeated monitoring program in 32 lakes known to contain G. lacustris, the species was detected by kick sampling in less than $50 \%$ of the lakes (Walseng et al. 1994, 1996). In a similar study, an artificial substrate (jute bags) and benthic littoral kick sampling were used in addition to stomach analyses of brown trout (Fjellheim et al. 2007). In these lakes where G. lacustris appeared in low numbers, only stomach analyses gave positive findings. Thus, we assume that fish stomach analysis is the most reliable method for detecting $G$. lacustris.

Our study revealed that the geographical distribution of $G$. lacustris on Hardangervidda is highly skewed. In the central and eastern area this crustacean is very common, being recorded in $79 \%$ of the lakes examined. In this area only $25 \%$ of the natural lakes $(\mathrm{N}=765)$ have so far been properly surveyed. This crustacean can be difficult to catch, and investigations that include more than two repeat samplings may be needed to be certain of detecting G. lacustris. Of the 188 lakes examined, only $38 \%$ have been investigated more than twice. Hence, the estimate of 147 localities hosting G. lacustris in this area should easily be increased by more targeted surveys. Gammarus lacustris has been reported from only two lakes (4\%) in western areas. Our study thus confirms the distribution pattern observed at the beginning of the 1970s (Anonymous 1974).

Besides the examined lakes, there are a large number of unnamed small lakes in this area. According to Økland \& Økland (2007), G. lacustris does not thrive in ponds, indicating that the environmental conditions in small bodies of water are not favourable to the completion of their perennial life cycle (Dahl 1915; Bjerknes 1974). This is probably because small water bodies are exposed to drying out and/or freezing solid (Dahl 1915). The smallest water body with $G$. lacustris yet reported on Hardangervidda is an unnamed headwater lake $\left(0.0128 \mathrm{~km}^{2}\right.$, NVE ID no. 181955) in the Sævra tributary in Lågen catchment (Fjellheim 2004). There are approximately 1600 unnamed lakes that are larger than this. Thus, there is a considerable potential for new records of $G$. lacustris in this part of the mountain plateau.

Even though $G$. lacustris can thrive in small water bodies, there was a significant increase in the proportion of lakes containing $G$. lacustris with lake size. Gammarus lacustris is intensively sought for by brown trout and we assume that the proximity to refugia is better in bigger lakes because it will reduce predator-prey encounters.

In the central/eastern area, there are ten reservoirs. Gammarus lacustris is highly susceptible to water amplitude variations of more than six m, when they normally become extinct after some time (Dahl 1932; Aass 1969; Økland \& Økland 2007). In reservoirs with such an impoundment regime, their abundance became too small to be of any significance as fish food. This fact is also evident in this study, as $G$. lacustris was of importance as fish food in only the three reservoirs which had a water level amplitude of less than six m (cf. Appendix 1). In the remaining seven reservoirs, with an amplitude $>11 \mathrm{~m}, G$. lacustris was only occasionally detected, in low numbers, in three of them (regulated from 11.1 to $39.1 \mathrm{~m}$ ).

\section{Environmental constraints may limit the distribution of Gammarus lacustris}

Rapid postmoult calcification of the exoskeleton is vital for all crustaceans (Rukke 2002). In gammarids, a significant proportion of the total body calcium must be generated after a moult. Rates of calcium influx rise in line with external calcium concentration until a saturation point is reached. Experimental studies revealed that adult G. lacustris required ambient calcium concentrations of 2.5 to 5.0 $\mathrm{mg} \mathrm{L}^{-1}$ to ensure complete calcification after moulting (Rukke 2002). When ambient calcium concentration is in the suboptimal range and down to the lower lethal threshold, remineralization of the exoskeleton is compromised, and reproduction and survival are threatened (Cairns \& Yan 2009). Hence, low calcium concentrations may limit the distribution and success of calcium-demanding crustaceans in softwater localities (Rukke 2002). In our study, it was clearly shown that the crustacean inhabits the more calcium rich lakes (Figure 3 ).

Gammarus lacustris is also very sensitive to low $\mathrm{pH}$ levels, and it is not normally found in waters with $\mathrm{pH}<6.0$ (Borgstrøm \& Hendrey 1976; Fjellheim \& Raddum 1990; Økland \& Økland 2007). In our study, $\mathrm{pH}$ seems to be less associated with the occurrence of G. lacustris (Figure 3). In natural lakes however, low calcium concentration often interferes with low $\mathrm{pH}$ levels and in such lakes, 
low $\mathrm{pH}$ may reinforce unfavorable conditions.

The western area, which is nearly free of G. lacustris, is extremely barren with a bedrock of granitic and dioritic gneisses, giving water low in calcium $\left(0.76 \pm 0.39 \mathrm{mg} \mathrm{L}^{-1}\right)$. The catchments in the central and eastern areas, which are rich in G. lacustris, has a thicker moraine cover and the water quality is much better with respect to calcium $\left(1.63 \pm 1.14 \mathrm{mg} \mathrm{L}^{-1}\right)$. In this area, G. lacustris has been recorded in 89 lakes, of which $28 \%$ had a calcium concentration $<1.0 \mathrm{mg} \mathrm{L}^{-1}$, eight of them with $\mathrm{pH}<6.0$ (cf. Table 3 ). As a result, G. lacustris can survive in lakes with rather low calcium content. In some of the mountain lakes in southeastern part of Norway, G. lacustris was found at calcium levels down to approximately $0.7 \mathrm{mg} \mathrm{L}^{-1}$ (Økland \& Økland 2007). These values from natural waters are significantly lower than the lower lethal threshold of approximately $1.0 \mathrm{mg} \mathrm{L}^{-1}$, as suggested by Cairns \& Yan (2009).

The lowest calcium values in our study were found in two acidified lakes; Svartevatnet and Svartevasstjørni in Lågen catchment. In 1993, calcium in these two lakes was measured at $0.28-0.35 \mathrm{mg} \mathrm{L}^{-1}$ (Fjellheim et al. 2002). A liming programme that aimed to improve the water quality in these two lakes started in 1994, which resulted in the re-appearance of G. lacustris in brown trout stomachs (Fjellheim et al. 2001, 2007). This may be due to the reintroduced specimens and/ or proximity to species refugia with better water quality in the lakes. After the liming programme ended in 2013, calcium concentration was re-established near to the pre-liming level with $0.33-0.42 \mathrm{mg}$ $\mathrm{L}^{-1}$. Despite $\mathrm{pH}>6.0, G$. lacustris was virtually absent. We therefore assume that calcium concentrations below $0.5 \mathrm{mg} \mathrm{L}^{-1}$ are lethal to G. lacustris. The lower lethal threshold of approximately $0.7 \mathrm{mg} \mathrm{L}^{-1}$ suggested for alpine lakes in Norway by Økland \& Økland (2007), supposed that $\mathrm{pH}$ should exceed 6.0 to support G. lacustris in lakes with low calcium content. However, in our study, eight lakes with G. lacustris in the central/eastern area had $\mathrm{pH}<6.0$ and a calcium concentration between 0.28 and $0.79 \mathrm{mg} \mathrm{L}^{-1}$. Gammarus lacustris living in such waters must be regarded as "living at the edge" of their physiological abilities. Consequently, its lower lethal threshold for calcium seems to be at $\sim 0.5 \mathrm{mg} \mathrm{L}^{-1}$, which is close to the value proposed by Økland \& Økland (2007) for mountain lakes.

Even though the lakes in the two areas have quite different levels of calcium, $28 \%$ of the lakes $(\mathrm{N}=89)$ with positive findings of G. lacustris in the central/eastern area have calcium concentration $<1.0 \mathrm{mg} \mathrm{L}^{-1}$ (cf. Table 3). Consequently, the calcium concentration in many lakes in the western area ought not to be critical for survival. Thus, additional stressors decisive for its absence in this part of Hardangervidda need to exist.

Water temperature is crucial to all aquatic crustaceans, having a significant impact on their growth, development and generation time (Wilhelm \& Schindler 2000; Rukke 2002; Økland \& Økland 2007). Gammarus lacustris has a wide latitudinal and altitudinal distribution in the Northern Hemisphere, indicating that it is well adapted to a wide range of thermal regimes. In mountain lakes in southern Norway, it appears to prefer summer temperatures between 10 to $14^{\circ} \mathrm{C}$ (Økland \& Økland 2007). Even though it tolerates a wide range of temperatures, a minimum thermal input is needed to reach maturity and completion of its life cycle. In Norway, the life cycle roughly spans one year in low-land lakes (Økland \& Økland 2007). However, in colder lakes at elevated altitudes it becomes perennial. On Hardangervidda, a two-year life cycle has been documented (Dahl 1915; Bjerknes 1974). In high-altitude Canadian lakes (>2300 m a.s.1.), a low thermal input is compensated for by prolonged development with a three-year life cycle (Wilhelm \& Schindler 2000). A perennial life cycle has also been recorded for G. lacustris living in a low-land cave with a significantly lower temperature than in a neighbouring surface lake (Østbye et al. 2018). This phenotypic plasticity in reproductive traits appears to be a key factor in the maintenance of successful populations in a wide range of aquatic habitats (Wilhelm $\&$ Schindler 2000).

On Hardangervidda, there is a steep fall in snow deposition from west to east, with $1151 \mathrm{~mm}$ in the Austdøla/Ljoso catchment in the west to only $292 \mathrm{~mm}$ in the Uvdalselvi catchment in the east (Table 1). All the western catchments have snow deposits $>700 \mathrm{~mm}$. This provides a significant delay in the ice break-up in the former area, resulting in colder lakes and shorter ice-free seasons (Borgstrøm 2016; Qvenild \& Hesthagen 2019).

In the central/eastern area, there was no significant variation in the occurrence of G. lacustris in lakes at altitudes of up to $1396 \mathrm{~m}$ a.s.l. They may also exist in some of the 34 lakes that are situated above this height. However, only two of them have so far been examined for this species, both with negative results. Nationwide, G. lacustris is commonly found in lakes at all altitudes, from sea level up to $1560 \mathrm{~m}$ a.s.l. (Økland \& Økland 2007). The thermal conditions vary significantly with elevation as a lapse rate in air temperature of about $0.6^{\circ} \mathrm{C} 100 \mathrm{~m}^{-1}$ elevation is highly reflected in the water temperature (Kvambekk \& Melvold 2010; Qvenild et al. 2018). As a result, both altitude and snow deposition provide a variety of temperature regimes in lakes on Hardangervidda.

Taken separately, temperature and water quality should not be decisive factors in determining the presence or absence of $G$. lacustris in the western lakes. In addition, life history and phenotypic traits may simply be functions of the living environment through, for example, temperature-diet-predation conditions (Wilhelm \& Schindler 2000; Cairns \& Yan 2009; Østbye et al. 2018). For this reason, additional stressors may contribute to the distribution pattern of G. lacustris seen on Hardangervidda. Temperature is the only environmental factor that significantly affects crustacean moulting frequency (Rukke 2002). Due to its lower temperature and shorter ice-free season and waters with low ionic strength (cf. Skjelkvåle \& Henriksen 1998) in the western lakes, these may also be more nutrient-poor with lower productivity (cf. Wilhelm \& Schindler 2000). Low ambient calcium concentrations have revealed significant negative effects on survival, growth and calcium content of G. lacustris. This may result in later onset of reproduction, reduced carapace rigidity and increased vulnerability to cannibalism and predation. Higher calcium requirement of neonates compared to adults may reinforce any negative effects on G. lacustris (Rukke 2002).

\section{Gammarus lacustris - a highly preferred food item for fish}

As a relatively large crustacean of up to two $\mathrm{cm}$ in length, G. lacustris has proved to be among the most important food items for brown trout in lakes on Hardangervidda, together with Lepidurus arcticus (Pallas, 1793) and Eurycercus lamellatus A.F.M. (Dahl 1917; Sømme 1941). The effects of brown trout predation on G. lacustris in Norwegian mountain lakes is well documented (Dahl 1915, 1917, 1930; Sømme 1941; Aass 1969; Museth \& Borgstrøm 2010; Qvenild \& Rognerud 2018). On Hardangervidda this is also the case for Arctic char (Dahl 1920; Aass 1969) and Eurasian minnow (Rognerud et al. 2003). In lakes that contain these two species in addition to brown trout, $G$. lacustris may occur in small numbers and be difficult to detect. In such cases, proximity to species refugia may be crucial.

\section{Possible effects of climate change}

Alpine ecosystems are expected to face pronounced impacts of climate change. For the Norwegian mainland as a whole, a general increase in 
precipitation has been observed since the 1980s (Hanssen-Bauer et al. 2017). This pattern is also seen on Hardangervidda, where the annual winter deposition has risen during the same period, including a greater number of snow-rich winters with a reduced variation in a direction from west to east (Qvenild et al. 2018). Increased precipitation impacts on the run-off, resulting in more dilute waters (Presthus Heggen et al. 2010). This may create even more hostile conditions for G. lacustris living in localities at critical levels of calcium.

A significant increase in spring-summer (May-September) air temperatures since the 1980s have also been documented for Hardangervidda (Qvenild et al. 2018). This trend may be reflected in warmer aquatic habitats (Kvambekk \& Melvold 2010; Lindholm et al. 2012; Qvenild et al. 2018). Warmer lakes in the eastern part of the plateau may be handled by G. lacustris through its phenotypic plasticity in the reproduction traits (cf. Wilhelm \& Schindler 2000). Even though $G$. lacustris is able to survive temperatures up to $26^{\circ} \mathrm{C}$, it should not exceed $18^{\circ} \mathrm{C}$ for longer periods (Wilhelm \& Schindler 2000). Thus, we consider that $G$. lacustris will be able to survive in larger lakes on Hardangervidda, especially in stratified lakes with colder refugia. In 2003-2016, maximum temperatures above $20^{\circ} \mathrm{C}$ were not measured in the lakes monitored by temperature loggers (Qvenild et al. 2018). However, in small and shallow lakes and ponds, a warming as projected towards 2100 may reduce the range of $G$. lacustris. This has already been experienced for another crustacean species such as the Arctic fairy shrimp (Branchinecta palludosa O.F.Müller 1788) (Lindholm et al. 2012, 2015). From a conservation point of view, a detailed mapping of G. lacustris is fundamental in order to document future range changes.

\section{ACKNOWLEDGEMENTS}

The authors gratefully acknowledge Roar Kjær for drawing the maps and Eirik Fjeld for support with the statistics. We also want to thank Per-Arne Amundsen and Michal Grabowski for critical comments to the manuscript.

\section{REFERENCES}

Aass P. 1969. Crustacea, especially Lepidurus arcticus Pallas, as brown trout food in Norwegian mountain reservoirs. Institute of Freshwater Research, Drottningholm. Report No 49: 183-201.

Amundsen T. 1976. Fiskeribiologiske undersøkelser for Dagalivassdraget 1974-75. Fiskerikonsulenten for Øst-Norge. Rapport Na IV-3.2. 285 pp. (In Norwegian).

Anonymous. 1974. Hardangervidda. Natur-Kulturhistorie-Samfunnsliv. Miljøverndepartementet (NOU: Norges offentlige utredninger). 1974:30 B. 352 pp. (In Norwegian).

Bjerknes V. 1974. Life cycle and reproduction of Gammarus lacustris G.O.Sars (Amphipoda) in a lake at Hardangervidda, Western Norway. Norwegian Journal of Zoology 22: 39-43.

Borgstrøm R. 2016. Auren på Hardangervidda er sterkt påverka av klimatilhøve. Naturen nr. 4-2016: 147-155. (In Norwegian). doi: 10.18261/issn. 1504-3118-2016-04-02

Borgstrøm R, Hendrey GR. 1976. pH tolerance of the first larval stages of Lepidurus arcticus (Pallas) and adult Gammarus lacustris G.O.Sars. SNSF-prosjektet, Oslo-Ås, Norway, IR 22/76: 1-37. (In Norwegian with an English summary).

Cairns A, Yan N. 2009. A review of the influence of low ambient calcium concentrations on freshwater daphniids, gammarids, and crayfish. Environmental Reviews, 17: 67-79. doi: 10.1139/a09-005
Dahl K. 1915. En studie over grundaatens eller matfloens (Gammarus pulex) biologi og utbredelse i Norge. Særtrykk av Norges Jæger- og Fiskerforenings Tidsskrift 1915. 32 pp. (In Norwegian).

Dahl K. 1917. Ørret og ørretvann. Studier og forsøk. J.W.Cappelens forlag. 182 pp. (In Norwegian).

Dahl K. 1920. Studier over røje i ørretvand. Norges Jæger- og Fiskerforenings Tidsskrift 1920: 233-248. (In Norwegian).

Dahl K. 1930. A study on the supplies of fish food organisms in Norwegian lakes. Skrifter utgitt av Det Norske Videnskaps-Akademi i Oslo. I. Mat.-Naturv. Klasse. 1930 No. 1. 58 pp.

Dahl K. 1932. Influence of water storage of food conditions on trout in Lake Paalsbufjord. Skrifter utgitt av Det Norske Videnskaps-Akademi i Oslo. I. Mat.-Naturv. Klasse. 1931. No. 4. 53 pp.

Fjellheim A. 2004. Virkning av rotenonbehandling på bunndyrsamfunnene i et område ved Stigstu, Hardangervidda. Lab. for Ferskvannsøkologi og Innlandsfiske, Bergen, Rapport nr. 122. 60 pp. (In Norwegian).

Fjellheim A, Raddum GG. 1990. Acid precipitation: biological monitoring of streams and lakes. The Science of the Total Environment, 96: 57-66.

Fjellheim A, Tysse $\AA$, Bjerknes V. 2001. Reappearance of highly acid sensitive invertebrates after liming of an alpine lake ecosystem. Water, Air and Soil Pollution 130: 1391-1396. doi: 10.1007/978-94-007-08105_79

Fjellheim A, Tysse $\AA$, Bjerknes V, Wright RF. 2002. Finprikkauren på Hardangervidda. DN-utredning 2002-1. 58 pp. (In Norwegian).

Fjellheim A, Tysse $\AA$, Bjerknes V. 2007. Fish Stomachs as a Biomonitoring Tool in Studies of Invertebrate Recovery. Water, Air and Soil Pollution 7: 293-300. doi: 10.1007/s11267-006-9074-x

Fjellheim A, Tysse A, Gåsdal O, Stakseng H. 2018. Finprikkauren på Hardangervidda. UNI Research Miljø - LFI, Univ. i Bergen. Årsrapport 2017. 14 pp. (In Norwegian).

Halvorsen G. 1973. Crustacea from the High Mountain Area Hardangervidda, South Norway. Reports from the High Mountain Ecology Research Station, Finse, Norway. University in Oslo. 1973:2. $17 \mathrm{pp}$.

Hanssen-Bauer I, Førland EJ, Haddeland I, Hisdal H, Lawrence D, Mayer S, Nesje A, Nilsen JEØ, Sandven S, Sandø AB, Sorteberg A, Ådlandsvik B. 2017. Climate in Norway 2100 - a knowledge base for climate adaption. The Norwegian Center for Climate Services (NCCS). Report no. 1/2017. 45 pp.

Huitfeldt-Kaas H. 1911. Indberetning om Fiskeriforholdene paa Hardangervidden. I: Indstilling fra Fjeldbeitekomiteen om Harangviddens Utnyttelse. Landbruksdepartementet. (Centraltrykkeriet, Kristiania). 106 pp. (In Norwegian).

Kvambekk AS, Melvold K. 2010. Long-term trends in water temperature and ice cover in the subalpine lake, Øvre Heimdalsvatn, and nearby lakes and rivers. Hydrobiologia (2010) 642: 47-60. doi: 10.1007/97890-481-9388-2 5

Lindholm M, Stordal F, Hessen DO, Moe SJ, Aass P. 2012. Climate driven range retraction of an Arctic freshwater crustacean. Freshwater Biology 57: 2591-2601. doi: 10.1111/fwb.12030

Lindholm M, Hessen DO, Færøvig PJ, Rognerud B, Andersen T, Stordal F. 2015. Is distribution of cold stenotherms constrained by temperature? The case of the Arctic fairy shrimp (Branchinecta palludosa O.F.Müller 1788). Journal of Thermal Biology 53: 46-52. doi: 10.1016/j.jtherbio.2015.08.005

Museth J, Borgstrøm R. 2010. Diet overlap between introduced European minnow (Phoxinus phoxinus) and young brown trout (Salmo trutta) in the lake, Øvre Heimdalsvatn: a result of abundant resources or forced niche overlap? Hydrobiologia (2010) 423: 93-100. doi: 10.1007/s10750010-0162-6

Presthus Heggen M, Birks HH, Anderson NJ. 2010. Long-term ecosystem dynamics of a small lake and its catchment in west Greenland. The Holocene 20(8): 1207-1222. doi: 10.1177/0959683610371995

Qvenild T. 2004. Hardangervidda. Fiske og fjelliv. Naturforlaget. 406 pp. (In Norwegian).

Qvenild T, Rognerud S. 2018. Ørreten på Hardangervidda. Klimaets 
betydning for årsklassestyrke og produksjon av fisk og næringsdyr i Sandvatn 2001-2017. Norsk institutt for vannforskning (NIVA). Rapport LNR 7267-2018. 34 pp. (In Norwegian with an English summary). http://hdl.handle.net/11250/2495753

Qvenild T, Fjeld E, Fjellheim A, Rognerud S, Tysse Å. 2018. Climatic effects on a cold stenotherm species Lepidurus arcticus (Branchiopoda, Notostraca) on the southern outreach of its distribution range. Fauna norvegica 38: 37-53. doi: 10.5324/fn.v38i0.2598

Qvenild T, Hesthagen T. 2019. Environmental conditions limit the distribution of Lepidurus arcticus (Branchiopoda, Notostraca) on the Hardangervidda mountain plateau, Southern Norway. Fauna norvegica 39: 77-110. doi: 10.5324/fn.v39i0.2687

Rognerud S, Borgstrøm R, Qvenild T, Tysse Å. 2003. Ørreten på Hardangervidda. Norsk institutt for vannforskning (NIVA). Rapport LNR 4712-2003. 68 pp. (In Norwegian). http://hdl.handle. net/11250/283325

Rukke NA. 2002. Effects of low calcium concentrations on two common freshwater crustaceans, Gammarus lacustris and Astacus astacus. Freshwater Ecology 16: 357-366. doi: 10.1046/j.1365-2435.2002.00637.x

Skjelkvåle BL, Henriksen A. 1998. Water chemistry, acidification status and critical loads for national parks; Hardangervidda. Norwegian Institute for Water Research, Report L.NO. 3895-98: 49 pp. (In Norwegian with an English summary). http://hdl.handle. net/11250/210017

Sømme ID. 1941. Ørretboka. Jacob Dybwads Forlag. Oslo (1941). 591 pp. (In Norwegian).

Walseng B, Halvorsen G, Schartau AKL. 1994. Ferskvannsbiologiske undersøkelser i Kvenna, 1978. Norsk institutt for naturforskning (NINA), Oppdragsmelding nr. 321-1994. 33 pp. (In Norwegian).

Walseng B, Raddum GG, Saksgård R, Schartau AKL. 1996. Ferskvannsbiologiske undersøkelser i Kvenna 1995, med fokus på indikatorarter som redskap i forsuringsovervåkingen. Norsk institutt for naturforskning (NINA), Oppdragsmelding nr. 433-1996. 36 pp. (In Norwegian).

Wilhelm FH, Schindler DW. 2000. Reproductive strategies of Gammarus lacustris (Crustacea: Amphipoda) along an elevation gradient. Functional Ecology 2000 14: 413-422. doi: 10.1046/j.13652435.2000.00426.x

Økland KA, Økland J. 2007. Ørretmaten vanlig marflo Gammarus lacustris i ferskvann i Norge - utbredelse og økologi. Fauna 60: 10-19. (In Norwegian).

Østbye K, Østbye E, Lien AM, Lee LR, Lauritzen S-E, Carlini DB. 2018. Morphology and life history divergence in cave and surface populations of Gammarus lacustris (L.). PLoS ONE 13(10): e0205556. doi: 10.1371/journal.pone. 0205556

Editorial responsibility: Anne Helene Tandberg.

This article is open-access and distributed under the terms of the Creative Commons Attribution 4.0 International license. This permits all noncommercial use, distribution, and reproduction in any medium, provided the original work is properly cited.

(http://creativecommons.org/licenses/by/4.0/). 
Appendix I. Specific information about 348 lakes in 27 catchments with 11 catchments in the western region (W) and 16 catchments in the central and eastern region (C/E) on Hardangervidda, of which 245 were surveyed for the occurrence of Gammarus lacustris. Reg indicates that a lake is regulated. The number of examinations is specified together with any associated positive records. The numbered references are given below the table.

\begin{tabular}{|c|c|c|c|c|c|c|c|c|c|c|c|c|c|c|c|c|}
\hline 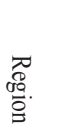 & & & 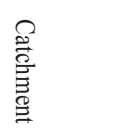 & $\begin{array}{l}z \\
\text { Ir } \\
\exists \\
\Xi \\
\Xi\end{array}$ & 产 & $\underset{\substack{\mathscr{Q} \\
\text { व̣a }}}{\overrightarrow{0}}$ & $\begin{array}{l}\Xi \\
\Xi \\
0 \\
\vdots \\
\vdots\end{array}$ & 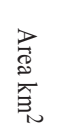 & & 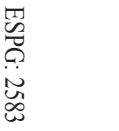 & 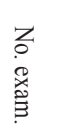 & 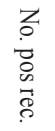 & 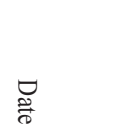 & 宗 & 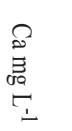 & 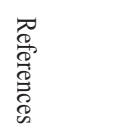 \\
\hline & & & & & & & & & $\mathrm{X}$ & Y & & & & & & \\
\hline W & 1 & & Austdøla & 16747 & Olbogavatnet & & 1194 & 0.35 & 70461 & 6741101 & 0 & & 07.08 .71 & 6.80 & 0.52 & 43 \\
\hline W & 1 & & Austdøla & 16781 & Reipstjørnane & & 1192 & 0.13 & 72883 & 6740013 & 0 & & 08.08 .71 & 6.90 & 0.32 & 43 \\
\hline W & 1 & & Austdøla & 16637 & $\begin{array}{l}\text { Vestre Memorge- } \\
\text { vatnet }\end{array}$ & & 1263 & 0.16 & 80149 & 6743690 & 0 & & 09.08 .71 & 7.00 & 1.68 & 43 \\
\hline W & 1 & & Austdøla & 1923 & $\begin{array}{l}\text { Søre Grøndals- } \\
\text { vatnet }\end{array}$ & & 1153 & 1.05 & 73417 & 6747708 & 0 & & 07.09 .68 & 5.60 & 0.64 & 112 \\
\hline W & 1 & & Austdøla & 16623 & Floskefonnvatnet & & 1081 & 0.19 & 70313 & 6745100 & 0 & & 11.09 .68 & 6.10 & 0.80 & 112 \\
\hline W & 1 & & Austdøla & 16664 & Austdalsvatnet & & 1161 & 0.32 & 75886 & 6742930 & 1 & 0 & 08.08 .71 & 6.90 & 1.20 & 43 \\
\hline W & 1 & & Austdøla & 1921 & Langvatnet & $\mathrm{x}$ & 1158 & 6.40 & 69287 & 6739016 & 2 & 0 & 06.08 .71 & 6.90 & 0.32 & 43,112 \\
\hline W & 1 & & Austdøla & 16656 & Austdalsvatnet & & 1059 & 0.08 & 72588 & 6743812 & 1 & 0 & & & & 46 \\
\hline W & 1 & & Austdøla & 16787 & Grasbotntjørni & & 1107 & 0.12 & 68354 & 6740315 & 1 & 0 & & & & 46 \\
\hline W & 1 & & Austdøla & 16677 & Rossevatni & & 954 & 0.09 & 69545 & 6743018 & 1 & 0 & & & & 46 \\
\hline W & 1 & & Austdøla & 1917 & Austdølnutvatnet & $\mathrm{x}$ & 1040 & 0.63 & 70590 & 6742742 & 2 & 0 & & & & 46,112 \\
\hline W & 1 & & Austdøla & 16712 & Austdølvatnet & & 907 & 0.13 & 68552 & 6742080 & 2 & 0 & & & & 46,112 \\
\hline W & 1 & & Austdøla & 16682 & Rossevatni & & 936 & 0.06 & 68971 & 6743002 & 2 & 0 & & & & 46,112 \\
\hline W & 1 & & Austdøla & 1918 & Rundavatnet & $\mathrm{x}$ & 1040 & 1.28 & 72020 & 6744428 & 2 & 0 & & & & 46,112 \\
\hline W & 1 & & Austdøla & 1922 & Kvilinganut-vatnet & & 1140 & 0.53 & 74117 & 6745937 & 1 & 0 & 09.09 .68 & 6.00 & 0.40 & 112 \\
\hline W & 2 & & Sima & 1915 & Holmavatn & & 1216 & 0.45 & 76822 & 6740581 & 0 & & 16.08 .67 & 6.70 & 1.00 & 112 \\
\hline W & 2 & & Sima & 1914 & Rembesdals-vatnet & & 905 & 1.29 & 76463 & 6735115 & 0 & & 27.07 .67 & 6.90 & 1.16 & 112 \\
\hline W & 2 & & Sima & 17050 & Skykkjedals-vatnet & & 837 & 0.43 & 75584 & 6731638 & 2 & 0 & 13.09 .08 & 6.65 & 1.48 & 46,60 \\
\hline $\mathrm{C} / \mathrm{E}$ & 3 & A & Isdølo & 1906 & Isdalsvatnet & & 832 & 1.07 & 76533 & 6726176 & 2 & 1 & 14.06 .88 & 6.52 & 2.12 & 46,56 \\
\hline $\mathrm{C} / \mathrm{E}$ & 3 & B & Leiro & 17369 & Svartetjørni & & 1141 & 0.14 & 90234 & 6721458 & 0 & & 04.08 .97 & 6.46 & 0.92 & 19 \\
\hline $\mathrm{C} / \mathrm{E}$ & 3 & B & Leiro & 17370 & Skardstjørnane & & 1126 & 0.12 & 90854 & 6721189 & 0 & & 17.08 .04 & 7.00 & 4.07 & 19 \\
\hline $\mathrm{C} / \mathrm{E}$ & 3 & B & Leiro & 17291 & Dalboretjern & & 1153 & 0.12 & 92974 & 6723206 & 1 & 0 & 04.08 .97 & 6.38 & 0.85 & 67 \\
\hline $\mathrm{C} / \mathrm{E}$ & 3 & B & Leiro & 17322 & Skardstjørnane & & 1124 & 0.29 & 91140 & 6721561 & 1 & 0 & 04.08 .97 & 6.51 & 1.91 & 67 \\
\hline $\mathrm{C} / \mathrm{E}$ & 3 & B & Leiro & 17289 & Halnetjørni & & 1259 & 0.16 & 96421 & 6722876 & 1 & 0 & & & & 67 \\
\hline $\mathrm{C} / \mathrm{E}$ & 3 & B & Leiro & 17402 & Dyratjørnane & & 1173 & 0.25 & 92219 & 6719647 & 2 & 0 & 04.08 .97 & 5.93 & 0.75 & 67 \\
\hline $\mathrm{C} / \mathrm{E}$ & 3 & B & Leiro & 17305 & Inste Olavsbu-vatn & & 1175 & 0.64 & 95206 & 6721531 & 2 & 2 & & & & 67 \\
\hline $\mathrm{C} / \mathrm{E}$ & 3 & B & Leiro & 17070 & Finsbergvatnet & & 1190 & 1.23 & 95280 & 6728945 & 1 & 0 & 01.06 .98 & 6.02 & 0.82 & 109 \\
\hline $\mathrm{C} / \mathrm{E}$ & 3 & B & Leiro & 17149 & Langavatnet & & 1124 & 0.74 & 91211 & 6726281 & 1 & 0 & 05.08 .99 & 6.03 & 0.62 & 110 \\
\hline $\mathrm{C} / \mathrm{E}$ & 3 & B & Leiro & 1907 & Sysenvatn & $\mathrm{x}$ & 880 & 10.42 & 82835 & 6722461 & 3 & 0 & 29.07 .67 & 6.60 & 0.88 & $46,56,112$ \\
\hline $\mathrm{C} / \mathrm{E}$ & 3 & $\mathrm{C}$ & Svinto & 17720 & Stigstutjørni & & 1218 & 0.05 & 94317 & 6706801 & 3 & 3 & & & & $3,34,74$ \\
\hline $\mathrm{C} / \mathrm{E}$ & 4 & & Bjoreio & 17673 & Nøkkatjørni & & 1353 & 0.115 & 80895 & 6710029 & 0 & & 09.10 .97 & 7.26 & 5.73 & 88 \\
\hline $\mathrm{C} / \mathrm{E}$ & 4 & & Bjoreio & 27430 & Tinnhølen & & 1213 & 4.54 & 90972 & 6704204 & 8 & 8 & 12.10 .97 & 7.05 & 4.16 & $\begin{array}{l}16,17,20 \\
56,67,71 \\
74,108\end{array}$ \\
\hline $\mathrm{C} / \mathrm{E}$ & 4 & & Bjoreio & 1910 & Langavatnet & & 1222 & 2.65 & 86436 & 6703503 & 4 & 3 & 09.10 .97 & 7.10 & 4.85 & $67,71,74$ \\
\hline $\mathrm{C} / \mathrm{E}$ & 4 & & Bjoreio & 17865 & $\begin{array}{l}\text { Kleivshovd- } \\
\text { tjørnane }\end{array}$ & & 1215 & 0.82 & 89929 & 6701871 & 4 & 4 & & & & $67,71,74$ \\
\hline $\mathrm{C} / \mathrm{E}$ & 5 & & Veig & 18157 & Meinsvatnet & & 1371 & 0.284 & 62964 & 6697312 & 0 & & 28.09 .89 & 6.53 & 1.08 & 88 \\
\hline $\mathrm{C} / \mathrm{E}$ & 5 & & Veig & 18103 & Langgrøvatnet & & 1347 & 0.325 & 65266 & 6698738 & 0 & & 09.10 .97 & 6.73 & 2.27 & 88 \\
\hline $\mathrm{C} / \mathrm{E}$ & 5 & & Veig & 18002 & Øvre Solvatnet & & 1320 & 0.264 & 59097 & 6701176 & 0 & & 09.10 .97 & 7.28 & 2.96 & 88 \\
\hline $\mathrm{C} / \mathrm{E}$ & 5 & & Veig & 17531 & Vassdalsvatni & & 1222 & 0.42 & 58355 & 6716740 & 1 & 0 & 09.10 .97 & 7.00 & 1.68 & 67 \\
\hline $\mathrm{C} / \mathrm{E}$ & 5 & & Veig & 17715 & Vatnalivatnet & & 1045 & 0.64 & 62617 & 6709369 & 1 & 0 & 09.10 .97 & 7.23 & 3.45 & 67 \\
\hline $\mathrm{C} / \mathrm{E}$ & 5 & & Veig & 18287 & Grytevatnet & & 1396 & 0.34 & 61722 & 6695491 & 1 & 0 & & & & 67 \\
\hline $\mathrm{C} / \mathrm{E}$ & 5 & & Veig & 17710 & Nautavad & & 1060 & 0.11 & 61616 & 6710060 & 1 & 0 & & & & 67 \\
\hline
\end{tabular}


Appendix I. Continued.

\begin{tabular}{|c|c|c|c|c|c|c|c|c|c|c|c|c|c|c|c|c|}
\hline 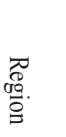 & & 5 & $\begin{array}{l}\stackrel{尺}{\approx} \\
\stackrel{\tilde{\tilde{c}}}{\tilde{E}} \\
\stackrel{0}{\rightleftarrows}\end{array}$ & $\begin{array}{l}z \\
z \\
\text { ry } \\
\exists \\
z \\
z\end{array}$ & 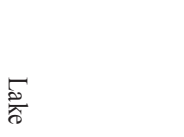 & 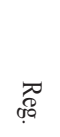 & 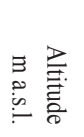 & 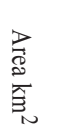 & & 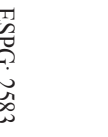 & 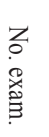 & 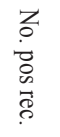 & $\begin{array}{l}\text { 융 } \\
\text { हैं }\end{array}$ & 草 & 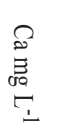 & 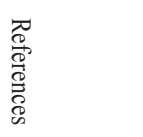 \\
\hline & & & & & & & & & $X$ & Y & & & & & & \\
\hline $\mathrm{C} / \mathrm{E}$ & 5 & & Veig & 18228 & Herrevatnet & & 1317 & 0.14 & 71445 & 6695987 & 1 & 1 & & & & 71 \\
\hline $\mathrm{C} / \mathrm{E}$ & 5 & & Veig & 18421 & Grøndalsvatni & & 1268 & 0.30 & 64263 & 6692710 & 1 & 1 & & & & 74 \\
\hline $\mathrm{C} / \mathrm{E}$ & 5 & & Veig & 17620 & Vivetjørnane & & 1009 & 0.16 & 64265 & 6713570 & 1 & 0 & & & 1.00 & 112 \\
\hline $\mathrm{C} / \mathrm{E}$ & 5 & & Veig & 67665 & Nedre Vivevatn & & 1009 & 0.02 & 64814 & 6713675 & 2 & 0 & & & & 112 \\
\hline $\mathrm{C} / \mathrm{E}$ & 5 & & Veig & 17614 & Reinavatnet & & 1082 & 0.26 & 61500 & 6714260 & 1 & 0 & & & & 117 \\
\hline $\mathrm{C} / \mathrm{E}$ & 5 & & Veig & 17975 & Vierslatjørn & & 1244 & 0.12 & 75911 & 6700837 & 2 & 1 & & & & 13,67 \\
\hline $\mathrm{C} / \mathrm{E}$ & 5 & & Veig & 17997 & Heisantjørnane & & 1244 & 0.20 & 76015 & 6699894 & 3 & 1 & 17.07.96 & 6.50 & 2.20 & $13,67,74$ \\
\hline $\mathrm{C} / \mathrm{E}$ & 5 & & Veig & 17849 & Bersavikvatnet & & 1231 & 1.65 & 59771 & 6704861 & 3 & 2 & 09.10 .97 & 7.26 & 3.32 & $3,67,116$ \\
\hline $\mathrm{C} / \mathrm{E}$ & 5 & & Veig & 18434 & Grøndalsvatni & & 1281 & 0.22 & 61784 & 6692865 & 3 & 1 & 09.10.97 & 7.15 & 3.08 & $40,67,74$ \\
\hline $\mathrm{C} / \mathrm{E}$ & 5 & & Veig & 18409 & Grøndalsvatni & & 1268 & 0.56 & 63593 & 6693034 & 3 & 2 & & & & 40,74 \\
\hline $\mathrm{C} / \mathrm{E}$ & 5 & & Veig & 17616 & Vasslivatn & & 1041 & 0.85 & 62549 & 6713510 & 3 & 1 & & & 0.96 & $67,112,117$ \\
\hline $\mathrm{C} / \mathrm{E}$ & 5 & & Veig & 17730 & Hanasteinsvatnet & & 1196 & 0.07 & 56589 & 6709950 & 2 & 2 & & & & 67,116 \\
\hline $\mathrm{C} / \mathrm{E}$ & 5 & & Veig & 17735 & Skinhovda & & 1152 & 0.50 & 59177 & 6709412 & 2 & 1 & & & & 67,116 \\
\hline $\mathrm{C} / \mathrm{E}$ & 5 & & Veig & 17737 & Tresnutvatnet & & 1193 & 0.22 & 57334 & 6709418 & 2 & 1 & & & & 67,116 \\
\hline $\mathrm{C} / \mathrm{E}$ & 5 & & Veig & 17668 & Langavatnet & & 1195 & 0.44 & 58651 & 6712245 & 2 & 1 & 09.10 .97 & 7.03 & 1.67 & 67,117 \\
\hline $\mathrm{C} / \mathrm{E}$ & 5 & & Veig & 18224 & Herrevatnet & & 1367 & 0.46 & 73027 & 6695197 & 3 & 3 & 09.10 .97 & 7.11 & 5.54 & 67,74 \\
\hline $\mathrm{C} / \mathrm{E}$ & 6 & A & Erdals-vassdr. & 27433 & Vetlevatnet & & 884 & 0.06 & 57341 & 6725553 & 1 & 1 & & & & 117 \\
\hline $\mathrm{C} / \mathrm{E}$ & 6 & A & Erdals-vassdr. & 17300 & Busetevatnet & & 884 & 0.43 & 58125 & 6726003 & 4 & 3 & 30.07 .67 & 6.90 & 1.40 & $\begin{array}{l}67,74,112, \\
117\end{array}$ \\
\hline W & 6 & B & Bjotveitelvi & 27428 & Vatnosetvatnet & & 869 & 0.44 & 52863 & 6726935 & 4 & 2 & & & & $3,67,74,117$ \\
\hline $\mathrm{C} / \mathrm{E}$ & 7 & A & Kinso & 27475 & Trollavatnet & & 1280 & 0.230 & 54314 & 6715304 & 0 & & 31.10 .95 & 6.60 & 1.40 & 88 \\
\hline $\mathrm{C} / \mathrm{E}$ & 7 & A & Kinso & 18214 & Sandvatnet & & 1363 & 0.87 & 59963 & 6697198 & 1 & 0 & 09.10 .97 & 7.16 & 2.32 & 67 \\
\hline $\mathrm{C} / \mathrm{E}$ & 7 & A & Kinso & 27527 & Gravdalsvatnet & & 1012 & 0.12 & 50169 & 6710198 & 1 & 0 & & & & 67 \\
\hline $\mathrm{C} / \mathrm{E}$ & 7 & A & Kinso & 27534 & Nasavatnet & & 1057 & 0.19 & 51466 & 6709620 & 1 & 0 & & & & 67 \\
\hline $\mathrm{C} / \mathrm{E}$ & 7 & A & Kinso & 27495 & Lonavatnet & & 1125 & 0.52 & 54075 & 6713136 & 2 & 0 & 09.10 .97 & 6.79 & 1.59 & 67 \\
\hline $\mathrm{C} / \mathrm{E}$ & 7 & A & Kinso & 27510 & Fodnastølsvatnet & & 955 & 0.33 & 50687 & 6712409 & 2 & 1 & 09.10 .97 & 7.22 & 3.89 & 67 \\
\hline $\mathrm{C} / \mathrm{E}$ & 7 & A & Kinso & 17878 & Kinsevatnet & & 1184 & 0.26 & 56181 & 6704912 & 2 & 0 & & & 3.32 & 67 \\
\hline $\mathrm{C} / \mathrm{E}$ & 7 & A & Kinso & 27500 & Kinsevatnet & & 940 & 0.21 & 49818 & 6712693 & 2 & 0 & & & & 67 \\
\hline $\mathrm{C} / \mathrm{E}$ & 7 & A & Kinso & 27573 & Sperrådalsvatn & & 1179 & 0.14 & 55531 & 6705279 & 1 & 0 & & & 2.44 & 112 \\
\hline $\mathrm{C} / \mathrm{E}$ & 7 & A & Kinso & 27478 & Stavalivatnet & & 900 & 0.69 & 49566 & 6715667 & 5 & 2 & & & 2.12 & $3,67,74,112$ \\
\hline $\mathrm{C} / \mathrm{E}$ & 7 & A & Kinso & 27476 & Rjuvavatnet & & 889 & 0.30 & 48598 & 6715537 & 2 & 0 & & & 2.24 & 67,112 \\
\hline $\mathrm{C} / \mathrm{E}$ & 7 & A & Kinso & 27523 & Austmannavatnet & & 1170 & 0.19 & 54407 & 6710520 & 3 & 2 & & & & 67,116 \\
\hline $\mathrm{C} / \mathrm{E}$ & 7 & A & Kinso & 27533 & Holmavatnet & & 1186 & 0.56 & 55661 & 6709363 & 3 & 3 & & & & 67,116 \\
\hline $\mathrm{C} / \mathrm{E}$ & 7 & A & Kinso & 27637 & $\begin{array}{l}\text { Omkjelsvatnet } \\
\text { Øvre }\end{array}$ & & 1202 & 0.55 & 53915 & 6699113 & 2 & 2 & 09.10 .97 & 7.07 & 1.93 & 67,70 \\
\hline $\mathrm{C} / \mathrm{E}$ & 7 & A & Kinso & 1913 & $\begin{array}{l}\text { Omkjelsvatnet } \\
\text { Nedre }\end{array}$ & & 1199 & 2.39 & 55086 & 6701409 & 3 & 3 & & & 2.32 & $67,74,112$ \\
\hline $\mathrm{C} / \mathrm{E}$ & 7 & A & Kinso & 1912 & Veivatnet & & 1172 & 4.68 & 53384 & 6706672 & 5 & 5 & & & 3.16 & $\begin{array}{l}67,74,112, \\
116\end{array}$ \\
\hline W & 7 & B & Vivippo & 27436 & Birgesdalsvatnet & & 1183 & 0.66 & 52528 & 6724099 & 1 & 0 & & & & 67 \\
\hline W & 7 & B & Vivippo & 27444 & Vassdalsvatnet & & 1122 & 0.43 & 48533 & 6723050 & 1 & 0 & & & & 67 \\
\hline W & 7 & B & Vivippo & 27450 & Grytingsvatn & & 700 & 0.24 & 48434 & 6721377 & 2 & 0 & & & & 67 \\
\hline W & 8 & & Opo & 27473 & Kjølevatni & & 1109 & 0.050 & 44306 & 6716792 & 0 & & 02.10 .97 & 6.14 & 0.71 & 88 \\
\hline W & 8 & & Opo & 27472 & Kjølevatni & & 1108 & 0.28 & 44724 & 6716168 & 1 & 0 & & 6.14 & 0.71 & 67 \\
\hline W & 8 & & Opo & 27528 & Yskjebotnvatnet & & 1105 & 0.75 & 43328 & 6709676 & 1 & 0 & 02.10 .97 & 6.59 & 0.93 & 67 \\
\hline W & 8 & & Opo & 27504 & Skriksetvatn & & 1016 & 0.19 & 42663 & 6713653 & 1 & 0 & & & & 67 \\
\hline W & 8 & & Opo & 1904 & Opesjovatnet & & 1014 & 1.25 & 44930 & 6712854 & 1 & 0 & 02.10 .97 & 6.65 & 0.94 & 112 \\
\hline W & 9 & $\mathrm{~A}$ & Espeelvi & 27611 & Mostjørn & & 1238 & 0.25 & 39059 & 6702750 & 1 & 0 & & & & 73 \\
\hline
\end{tabular}


Appendix I. Continued.

\begin{tabular}{|c|c|c|c|c|c|c|c|c|c|c|c|c|c|c|c|c|}
\hline 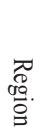 & & & 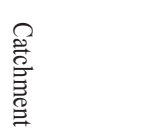 & 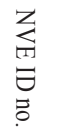 & $\overrightarrow{\vec{\nabla}}$ & 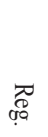 & 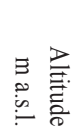 & 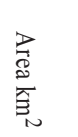 & & 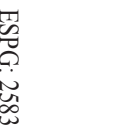 & 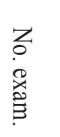 & 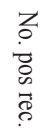 & 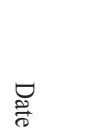 & 茫 & 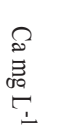 & 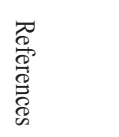 \\
\hline & & & & & & & & & $\mathrm{X}$ & $\mathrm{Y}$ & & & & & & \\
\hline W & 9 & B & Vendo & 1903 & Store Vendevatnet & $\mathrm{x}$ & 1268 & 3.64 & 41667 & 6704733 & 2 & 0 & 01.08 .10 & 6.80 & 1.28 & $56,58,112$ \\
\hline W & 10 & & Tysso & 27762 & Løkene & & 1309 & 0.157 & 49829 & 6683280 & 0 & & 09.10 .97 & 6.08 & 0.69 & 88 \\
\hline W & 10 & & Tysso & 18713 & Jukletjørn & & 1431 & 0.522 & 56089 & 6688253 & 0 & & 15.09 .97 & 6.23 & 0.59 & 88 \\
\hline W & 10 & & Tysso & 27600 & Illakleivløkene & & 1362 & 1.283 & 50388 & 6701774 & 0 & & 09.10 .97 & 6.29 & 0.43 & 88 \\
\hline W & 10 & & Tysso & 18887 & Juklevatni & & 1430 & 0.381 & 56982 & 6684844 & 0 & & 09.10 .97 & 6.31 & 0.41 & 88 \\
\hline W & 10 & & Tysso & 27668 & Selsløken & & 1323 & 0.557 & 52128 & 6695930 & 0 & & 09.10 .97 & 6.51 & 0.53 & 88 \\
\hline W & 10 & & Tysso & 27680 & Tyssehølen & & 1162 & 0.11 & 43332 & 6695188 & 1 & 0 & & & & 56 \\
\hline W & 10 & & Tysso & 1898 & $\begin{array}{l}\text { Nedre } \\
\text { Håvardsvatn }\end{array}$ & $\mathrm{x}$ & 1264 & 5.46 & 54458 & 6690703 & 5 & 0 & 01.08 .10 & 6.67 & 1.03 & 56,57 \\
\hline W & 10 & & Tysso & 27661 & Hadletgrøna & & 1264 & 0.35 & 42541 & 6697205 & 1 & 0 & & & & 73 \\
\hline W & 10 & & Tysso & 27758 & Hattasteins-vatnet & & 1287 & 0.92 & 47553 & 6683669 & 1 & 0 & & & & 73 \\
\hline W & 10 & & Tysso & 27693 & Langtjørn & & 1305 & 0.27 & 45054 & 6692759 & 1 & 0 & & & & 73 \\
\hline W & 10 & & Tysso & 27669 & $\begin{array}{l}\text { Nedre } \\
\text { Veidedalsvatn }\end{array}$ & & 1312 & 0.15 & 47503 & 6696107 & 1 & 0 & & & & 73 \\
\hline W & 10 & & Tysso & 27682 & Reinakolltjørn & & 1359 & 0.18 & 45595 & 6694481 & 1 & 0 & & & & 73 \\
\hline W & 10 & & Tysso & 27677 & $\begin{array}{l}\text { Øvre } \\
\text { Veidedalsvatn }\end{array}$ & & 1333 & 0.22 & 49095 & 6694926 & 1 & 0 & & & & 73 \\
\hline W & 10 & & Tysso & 1892 & Nonskardvatnet & & 1284 & 1.39 & 54087 & 6693281 & 2 & 0 & 09.10 .97 & 6.67 & 0.95 & 73,113 \\
\hline W & 10 & & Tysso & 1889 & Ringedalsvatnet & $\mathrm{x}$ & 464 & 7.25 & 39127 & 6694395 & 5 & 0 & & & & $\begin{array}{l}12,56,79 \\
113\end{array}$ \\
\hline W & 10 & & Tysso & 1901 & Langevatnet & $\mathrm{x}$ & 1190 & 6.36 & 41622 & 6687621 & 5 & 0 & 01.08 .10 & 6.28 & 0.53 & $\begin{array}{l}56,57,58 \\
73,113\end{array}$ \\
\hline W & 10 & & Tysso & 27663 & Holmevatn & & 1271 & 0.84 & 45895 & 6696516 & 4 & 0 & 01.08 .10 & 6.36 & 0.64 & $\begin{array}{l}56,58,73, \\
113\end{array}$ \\
\hline W & 10 & & Tysso & 1890 & Øvre Tyssevatn & $\mathrm{x}$ & 1333 & 2.92 & 49307 & 6698163 & 4 & 0 & 01.08 .10 & 6.38 & 0.64 & $\begin{array}{l}56,58,73, \\
113\end{array}$ \\
\hline W & 10 & & Tysso & 1894 & Nibbehølen & $\mathrm{x}$ & 1191 & 2.06 & 46031 & 6690183 & 4 & 0 & 01.08 .10 & 6.40 & 0.64 & $\begin{array}{l}56,58,73, \\
113\end{array}$ \\
\hline W & 10 & & Tysso & 27672 & Stednesvatnet & & 1213 & 0.15 & 44070 & 6695812 & 2 & 0 & & & & 56,73 \\
\hline W & 10 & & Tysso & 1902 & Breidavatn & $\mathrm{x}$ & 1232 & 3.35 & 47989 & 6685761 & 3 & 0 & & & & $56,73,113$ \\
\hline W & 10 & & Tysso & 1900 & Nedre Bersåvatnet & $\mathrm{x}$ & 1029 & 0.88 & 37725 & 6698727 & 3 & 0 & & & & $56,73,113$ \\
\hline W & 10 & & Tysso & 27650 & Nedre Tyssevatn & & 1317 & 0.43 & 48130 & 6697391 & 3 & 0 & & & & $56,73,113$ \\
\hline W & 10 & & Tysso & 1893 & Øvre Bersåvatnet & $\mathrm{x}$ & 1106 & 3.37 & 41421 & 6699804 & 3 & 0 & & & & $56,73,113$ \\
\hline W & 10 & & Tysso & 1897 & Øvre Nybuvatnet & & 1191 & 0.68 & 50202 & 6690302 & 3 & 0 & & & & $56,73,113$ \\
\hline W & 11 & & $\begin{array}{l}\text { Austdølo/ } \\
\text { Ljoso }\end{array}$ & 1703 & Isvatnet & & 1223 & 1.785 & 44738 & 6676790 & 0 & & 21.09 .95 & 5.35 & 0.38 & 88 \\
\hline W & 11 & & $\begin{array}{l}\text { Austdølo/ } \\
\text { Ljoso }\end{array}$ & 27797 & Søre Blåvatnet & & 1219 & 0.617 & 44889 & 6681121 & 0 & & 09.10 .97 & 5.66 & 0.33 & 88 \\
\hline W & 11 & & $\begin{array}{l}\text { Austdølo/ } \\
\text { Ljoso }\end{array}$ & 23168 & Raudnosvatnet & & 978 & 0.233 & 42015 & 6675600 & 0 & & 02.10 .97 & 5.95 & 0.37 & 88 \\
\hline W & 11 & & $\begin{array}{l}\text { Austdølo/ } \\
\text { Ljoso }\end{array}$ & 23143 & Ljosevatn & & 630 & 0.57 & 38106 & 6678046 & 1 & 0 & & & & 67 \\
\hline W & 11 & & $\begin{array}{l}\text { Austdølo/ } \\
\text { Ljoso }\end{array}$ & 1702 & Reinsnosvatnet & & 594 & 3.35 & 37648 & 6675989 & 1 & 0 & & & & 67 \\
\hline W & 11 & & $\begin{array}{l}\text { Austdølo/ } \\
\text { Ljoso }\end{array}$ & 23161 & Svartavatn & & 813 & 0.26 & 41372 & 6676488 & 1 & 0 & & & & 67 \\
\hline W & 12 & & Suldalsvassdr. & 23154 & Grønhellervatn & & 1006 & 0.111 & 50924 & 6676616 & 0 & & 02.10 .97 & 5.93 & 0.60 & 88 \\
\hline W & 12 & & Suldalsvassdr. & 11783 & Vivassvatnet & & 930 & 0.476 & 52601 & 6675590 & 0 & & 02.10 .97 & 6.17 & 0.79 & 88 \\
\hline W & 12 & & Suldalsvassdr. & 1866 & Valldalsvatnet & $\mathrm{x}$ & 745 & 7.33 & 50628 & 6672273 & 2 & 0 & 01.08 .11 & 6.33 & 0.63 & 56,59 \\
\hline W & 13 & & Bora & 12157 & Nedre Poddevatnet & & 1203 & 0.39 & 66134 & 6665519 & 0 & & 15.09 .83 & 6.50 & 1.68 & 42 \\
\hline W & 13 & & Bora & 85 & Holmasjøen & & 1261 & 1.888 & 63572 & 6667242 & 0 & & 21.09 .95 & 5.84 & 0.36 & 88 \\
\hline
\end{tabular}


Appendix I. Continued.

\begin{tabular}{|c|c|c|c|c|c|c|c|c|c|c|c|c|c|c|c|}
\hline 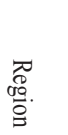 & 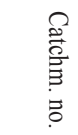 & 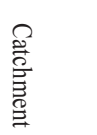 & $\begin{array}{l}\text { Z } \\
\text { II } \\
\text { छ } \\
\vdots\end{array}$ & $\underset{\overrightarrow{2}}{\stackrel{2}{\delta}}$ & 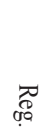 & 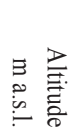 & 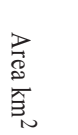 & & 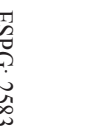 & $\begin{array}{l}\text { Zz } \\
0 \\
0 \\
0 \\
0\end{array}$ & $\begin{array}{l}z \\
0 \\
\dot{0} \\
0 \\
\overrightarrow{0} \\
?\end{array}$ & 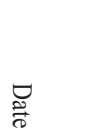 & 䓋 & 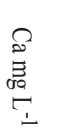 & 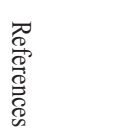 \\
\hline & & & & & & & & $\mathrm{X}$ & $\mathrm{Y}$ & & & & & & \\
\hline W & 13 & Bora & 12118 & Åremotvatni & $\mathrm{x}$ & 1180 & 1.13 & 68743 & 6665138 & 1 & 0 & 15.09 .83 & 5.90 & 1.08 & 94 \\
\hline W & 13 & Bora & 55 & Bordalsvatnet & $\mathrm{x}$ & 891 & 7.69 & 70888 & 6656673 & 5 & 3 & 15.09 .83 & 6.50 & 2.62 & $\begin{array}{l}65,68,93, \\
99\end{array}$ \\
\hline $\mathrm{C} / \mathrm{E}$ & 14 & Songa & 25 & Storhellervatnet & & 1108 & 0.56 & 72762 & 6664387 & 0 & & 12.09 .04 & 6.20 & 0.76 & 42 \\
\hline $\mathrm{C} / \mathrm{E}$ & 14 & Songa & 19129 & Tangasjøen & & 1401 & 0.405 & 64777 & 6678455 & 0 & & 02.10 .97 & 6.82 & 2.10 & 88 \\
\hline $\mathrm{C} / \mathrm{E}$ & 14 & Songa & 12029 & Gjevdøltjørni & & 1285 & 0.19 & 85697 & 6667223 & 0 & & 13.09 .83 & 6.03 & 0.62 & 89 \\
\hline $\mathrm{C} / \mathrm{E}$ & 14 & Songa & 12092 & Nedre Berutjørni & & 1242 & 0.13 & 81943 & 6665987 & 1 & 0 & 15.09 .83 & 5.80 & 0.96 & 42 \\
\hline $\mathrm{C} / \mathrm{E}$ & 14 & Songa & 12024 & Midtre Berutjørni & & 1289 & 0.23 & 81376 & 6667306 & 1 & 0 & 02.10 .97 & 6.22 & 0.52 & 42 \\
\hline $\mathrm{C} / \mathrm{E}$ & 14 & Songa & 11743 & Hedlevatnet & & 1161 & 2.07 & 67627 & 6674859 & 1 & 1 & 02.10 .97 & 6.75 & 2.04 & 42 \\
\hline $\mathrm{C} / \mathrm{E}$ & 14 & Songa & 11904 & Filleherberg-vatnet & & 1149 & 0.36 & 70429 & 6671441 & 1 & 0 & & & & 42 \\
\hline $\mathrm{C} / \mathrm{E}$ & 14 & Songa & 11808 & Merakktjørni & & 1291 & 0.46 & 83274 & 6672489 & 1 & 0 & & & & 42 \\
\hline $\mathrm{C} / \mathrm{E}$ & 14 & Songa & 11933 & Øvre Berutjørni & & 1307 & 0.42 & 81745 & 6669624 & 2 & 1 & 12.09 .84 & 6.00 & 0.62 & 42,64 \\
\hline $\mathrm{C} / \mathrm{E}$ & 14 & Songa & 11786 & Bamsetjønn & & 1348 & 0.12 & 74737 & 6673951 & 2 & 1 & & & & 42,75 \\
\hline $\mathrm{C} / \mathrm{E}$ & 14 & Songa & 11734 & Store Urevatnet & & 1255 & 1.00 & 72331 & 6674883 & 2 & 2 & 15.09 .83 & 6.60 & 3.11 & 67,74 \\
\hline $\mathrm{C} / \mathrm{E}$ & 14 & Songa & 12021 & Fjarefittjørni & & 1176 & 0.04 & 78159 & 6668176 & 1 & 1 & & & & 75 \\
\hline $\mathrm{C} / \mathrm{E}$ & 14 & Songa & 10 & Songa & $\mathrm{x}$ & 974 & 30.01 & 82524 & 6659180 & 12 & 5 & 12.09 .84 & 6.40 & 1.63 & $\begin{array}{l}14,64,74, \\
84,92,100\end{array}$ \\
\hline $\mathrm{C} / \mathrm{E}$ & 14 & Songa & 12030 & Ugletjørni & & 1195 & 0.88 & 87497 & 6666718 & 1 & 0 & 02.10 .97 & 6.30 & 0.53 & Own data \\
\hline $\mathrm{C} / \mathrm{E}$ & 15 & Kvenna & 18910 & Tjønndalstjønnane & & 1205 & 0.35 & 90674 & 6681005 & 0 & & 15.09 .83 & 6.30 & 2.04 & 42 \\
\hline $\mathrm{C} / \mathrm{E}$ & 15 & Kvenna & 11937 & Ormetjørni & & 1273 & 0.726 & 84810 & 6669553 & 0 & & 24.09 .86 & 5.92 & 0.61 & 88 \\
\hline $\mathrm{C} / \mathrm{E}$ & 15 & Kvenna & 18735 & Kollstjørn & & 1332 & 0.595 & 58549 & 6688256 & 0 & & 15.09 .97 & 6.31 & 0.65 & 88 \\
\hline $\mathrm{C} / \mathrm{E}$ & 15 & Kvenna & 19228 & Vollenuttjørnan & & 1303 & 0.204 & 95786 & 6674151 & 0 & & 02.10 .97 & 6.39 & 0.73 & 88 \\
\hline $\mathrm{C} / \mathrm{E}$ & 15 & Kvenna & 18894 & Mjågevatn & & 1148 & 0.703 & 95370 & 6680696 & 0 & & 02.10 .97 & 6.64 & 1.01 & 88 \\
\hline $\mathrm{C} / \mathrm{E}$ & 15 & Kvenna & 11729 & Brutjørnane & & 1250 & 0.289 & 82473 & 6674617 & 0 & & 02.10 .97 & 6.67 & 1.37 & 88 \\
\hline $\mathrm{C} / \mathrm{E}$ & 15 & Kvenna & 18660 & Storhellertjørni & & 1270 & 0.153 & 101243 & 6685788 & 0 & & 21.09 .94 & 6.16 & 0.38 & 106 \\
\hline $\mathrm{C} / \mathrm{E}$ & 15 & Kvenna & 18523 & Elsjåen & & 1233 & 0.082 & 95298 & 6688551 & 0 & & 21.09 .94 & 6.76 & 1.94 & 106 \\
\hline $\mathrm{C} / \mathrm{E}$ & 15 & Kvenna & 12173 & Kostveitvatnet & & 1390 & 0.93 & 96393 & 6661411 & 2 & 0 & 13.09 .83 & 5.78 & 0.64 & 42,54 \\
\hline $\mathrm{C} / \mathrm{E}$ & 15 & Kvenna & 12135 & Hokkebrotvatnet & & 1383 & 0.52 & 94405 & 6663497 & 2 & 2 & 13.09 .83 & 5.81 & 0.69 & 42,54 \\
\hline $\mathrm{C} / \mathrm{E}$ & 15 & Kvenna & 11763 & Møruvatnet & & 1163 & 0.47 & 89964 & 6673078 & 1 & 0 & 02.10 .97 & 6.22 & 0.82 & 48 \\
\hline $\mathrm{C} / \mathrm{E}$ & 15 & Kvenna & 38 & Skardvatnet & & 1149 & 0.97 & 93901 & 6682778 & 2 & 2 & & & & 51,74 \\
\hline $\mathrm{C} / \mathrm{E}$ & 15 & Kvenna & 18545 & Sledalsvatnet & & 1288 & 0.43 & 58269 & 6691313 & 1 & 0 & & & & 53 \\
\hline $\mathrm{C} / \mathrm{E}$ & 15 & Kvenna & 18831 & Vassdalsvatni & & 1299 & 0.74 & 59870 & 6685608 & 1 & 0 & & & & 53 \\
\hline $\mathrm{C} / \mathrm{E}$ & 15 & Kvenna & 18919 & Tuevatni & & 1282 & 0.36 & 69955 & 6682678 & 1 & 0 & & & & 70 \\
\hline $\mathrm{C} / \mathrm{E}$ & 15 & Kvenna & 78 & Gjuvsjåen & & 1210 & 5.11 & 101369 & 6681191 & 1 & 1 & 21.09 .95 & 6.44 & 0.66 & 74 \\
\hline $\mathrm{C} / \mathrm{E}$ & 15 & Kvenna & 18495 & Grottjørnanene & & 1322 & 0.44 & 71055 & 6690732 & 1 & 1 & 10.07 .78 & 6.60 & 3.46 & 114 \\
\hline $\mathrm{C} / \mathrm{E}$ & 15 & Kvenna & 15 & $\begin{array}{l}\text { Nedre } \\
\text { Bjørnavatnet }\end{array}$ & & 1136 & 2.13 & 75023 & 6679965 & 2 & 0 & 02.10 .97 & 6.78 & 2.13 & 114,115 \\
\hline $\mathrm{C} / \mathrm{E}$ & 15 & Kvenna & 18700 & Kollsvatnet & & 1182 & 0.61 & 61644 & 6688435 & 9 & 0 & 11.09 .97 & 6.70 & 1.50 & 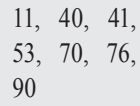 \\
\hline $\mathrm{C} / \mathrm{E}$ & 15 & Kvenna & 43 & Litlosvatnet & & 1170 & 1.52 & 63673 & 6686656 & 8 & 7 & 15.08 .95 & 6.56 & 1.19 & $\begin{array}{l}11,40,52, \\
70,87,114, \\
115\end{array}$ \\
\hline $\mathrm{C} / \mathrm{E}$ & 15 & Kvenna & 19 & Kvennsjøen & & 1166 & 5.00 & 66324 & 6684631 & 5 & 5 & 15.08 .95 & 6.62 & 1.43 & $\begin{array}{l}16,52,70, \\
74,114\end{array}$ \\
\hline $\mathrm{C} / \mathrm{E}$ & 15 & Kvenna & 18511 & Reinavatnet & & 1327 & 0.63 & 79782 & 6689329 & 2 & 1 & 31.07 .03 & 6.96 & 2.40 & 19,67 \\
\hline $\mathrm{C} / \mathrm{E}$ & 15 & Kvenna & 18556 & Valgardsvatni & & 1322 & 0.80 & 72971 & 6689771 & 2 & 1 & & & & 3,67 \\
\hline $\mathrm{C} / \mathrm{E}$ & 15 & Kvenna & 276148 & Sandhyl & & 1027 & 0.52 & 98546 & 6675337 & 2 & 2 & & & & 3,74 \\
\hline
\end{tabular}


Appendix I. Continued.

\begin{tabular}{|c|c|c|c|c|c|c|c|c|c|c|c|c|c|c|c|}
\hline 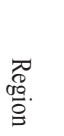 & 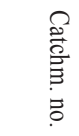 & 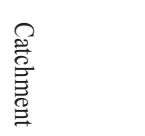 & 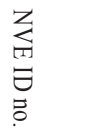 & $\frac{\overrightarrow{2}}{\stackrel{2}{\hat{\sigma}}}$ & $\underset{\substack{\mathbb{Q} \\
\text { ণa }}}{\not{a}}$ & $\begin{array}{l}\Xi \\
\Xi \\
0 \\
\omega \\
\vdots\end{array}$ & 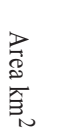 & & مُ & 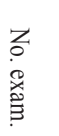 & $\begin{array}{l}z \\
\vdots \\
\dot{0} \\
\dot{0} \\
\stackrel{0}{0} \\
?\end{array}$ & $\begin{array}{l}\underset{D}{\overrightarrow{0}} \\
\stackrel{\overrightarrow{0}}{ }\end{array}$ & 焉 & 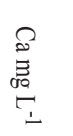 & 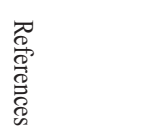 \\
\hline & & & & & & & & $X$ & $\mathrm{Y}$ & & & & & & \\
\hline $\mathrm{C} / \mathrm{E}$ & 15 & Kvenna & 18597 & Skavatn & & 1249 & 0.47 & 64063 & 6690187 & 5 & 3 & 08.07 .78 & 6.70 & 5.04 & $\begin{array}{l}40,41,53 \\
74,114\end{array}$ \\
\hline $\mathrm{C} / \mathrm{E}$ & 15 & Kvenna & 18782 & Vassdalsvatni & & 1282 & 0.45 & 61466 & 6686400 & 2 & 0 & 15.09 .97 & 6.26 & 1.25 & 40,53 \\
\hline $\mathrm{C} / \mathrm{E}$ & 15 & Kvenna & 41 & Store Meinsvatn & & 1384 & 1.40 & 93738 & 6667249 & 4 & 4 & 12.09 .84 & 5.90 & 0.59 & $\begin{array}{l}42,54,74, \\
114\end{array}$ \\
\hline $\mathrm{C} / \mathrm{E}$ & 15 & Kvenna & 12053 & Kolsnutgrysline & & 1386 & 0.50 & 97056 & 6665449 & 3 & 2 & 15.09 .83 & 5.50 & 0.79 & $42,74,114$ \\
\hline $\mathrm{C} / \mathrm{E}$ & 15 & Kvenna & 18558 & Krokavatnet & & 1236 & 0.42 & 60847 & 6691012 & 7 & 2 & 06.07 .78 & 6.80 & 2.57 & $\begin{array}{l}45,53,70 \\
74,90,114\end{array}$ \\
\hline $\mathrm{C} / \mathrm{E}$ & 15 & Kvenna & 13 & Briskevatnet & & 1068 & 2.62 & 89550 & 6677403 & 5 & 5 & 15.09 .83 & 6.60 & 3.74 & $\begin{array}{l}48,50,74, \\
77\end{array}$ \\
\hline $\mathrm{C} / \mathrm{E}$ & 15 & Kvenna & 12 & Vollevatnet & & 1030 & 1.66 & 94853 & 6676114 & 6 & 6 & 13.09 .83 & 6.63 & 1.33 & $\begin{array}{l}49, \quad 50,74 \\
77,114\end{array}$ \\
\hline $\mathrm{C} / \mathrm{E}$ & 15 & Kvenna & 19079 & Honserudvatnet & & 1045 & 0.38 & 93458 & 6676917 & 3 & 0 & & & & 49,77 \\
\hline $\mathrm{C} / \mathrm{E}$ & 15 & Kvenna & 14 & Gunleiksbuvatnet & & 1071 & 1.29 & 85362 & 6678032 & 6 & 5 & 15.08 .95 & 6.62 & 1.59 & $\begin{array}{l}50,74,77, \\
114,115\end{array}$ \\
\hline $\mathrm{C} / \mathrm{E}$ & 15 & Kvenna & 17 & Sandvatn & & 1112 & 1.57 & 82122 & 6681359 & 16 & 16 & 12.09 .84 & 6.40 & 1.15 & $\begin{array}{l}50,74,81, \\
82, \text { own data }\end{array}$ \\
\hline $\mathrm{C} / \mathrm{E}$ & 15 & Kvenna & 18854 & Kringlesjåen & & 1255 & 0.72 & 89249 & 6682690 & 5 & 0 & 17.08 .95 & 6.31 & 0.64 & $\begin{array}{l}51,114,115 \\
\text { own data }\end{array}$ \\
\hline $\mathrm{C} / \mathrm{E}$ & 15 & Kvenna & 39 & Fjellsjåen & & 1195 & 2.31 & 90148 & 6684863 & 7 & 6 & 16.08 .95 & 6.37 & 0.74 & $\begin{array}{l}51,114,115 \\
\text { own data }\end{array}$ \\
\hline $\mathrm{C} / \mathrm{E}$ & 15 & Kvenna & 18827 & Dargesjåen & & 1205 & 0.64 & 87775 & 6683553 & 7 & 5 & 17.08 .95 & 6.30 & 0.67 & $\begin{array}{l}\text { 51, 86, 114, } \\
115, \text { own } \\
\text { data }\end{array}$ \\
\hline $\mathrm{C} / \mathrm{E}$ & 15 & Kvenna & 16 & Øvre Bjørnavatnet & & 1147 & 2.92 & 71335 & 6679440 & 5 & 2 & 15.08 .95 & 6.53 & 1.46 & $\begin{array}{l}52,70,74, \\
114\end{array}$ \\
\hline $\mathrm{C} / \mathrm{E}$ & 15 & Kvenna & 18773 & Krokavatni & & 1150 & 1.21 & 72085 & 6684881 & 2 & 2 & & & & 52,74 \\
\hline $\mathrm{C} / \mathrm{E}$ & 15 & Kvenna & 66946 & Midtre Krokavatn & & 1141 & 0.93 & 74249 & 6684438 & 2 & 2 & & & & 52,74 \\
\hline $\mathrm{C} / \mathrm{E}$ & 15 & Kvenna & 18 & Nedre Krokavatn & & 1141 & 1.16 & 77610 & 6684108 & 3 & 2 & 03.07 .78 & 6.70 & 2.73 & $52,74,114$ \\
\hline $\mathrm{C} / \mathrm{E}$ & 15 & Kvenna & 42 & Valgardsvatni & & 1319 & 1.84 & 74012 & 6688631 & 4 & 4 & 16.08 .95 & 6.36 & 1.42 & $\begin{array}{l}67,70,74, \\
114\end{array}$ \\
\hline $\mathrm{C} / \mathrm{E}$ & 15 & Kvenna & 40 & Urdevatnet & & 1329 & 1.55 & 93521 & 6669198 & 5 & 4 & 16.08 .95 & 6.00 & 0.44 & $74,114,115$ \\
\hline $\mathrm{C} / \mathrm{E}$ & 15 & Kvenna & 11836 & Vesle Meinsvatnet & & 1353 & 0.57 & 95821 & 6670235 & 5 & 4 & 16.08 .95 & 6.05 & 0.46 & $74,114,115$ \\
\hline $\mathrm{C} / \mathrm{E}$ & 15 & Kvenna & 18581 & Ambjørsvatnet & & 1269 & 0.81 & 66343 & 6689682 & 3 & 1 & 11.09 .97 & 6.60 & 2.33 & $8,40,74$ \\
\hline $\mathrm{C} / \mathrm{E}$ & 15 & Kvenna & 18770 & Blånuttjørnane & & 1310 & 0.31 & 83830 & 6685129 & 1 & 1 & 09.10 .97 & 6.72 & 2.30 & 80 \\
\hline $\mathrm{C} / \mathrm{E}$ & 15 & Kvenna & 18923 & Tuevatni & & 1288 & 0.26 & 68807 & 6682727 & 1 & 1 & & & & 70 \\
\hline $\mathrm{C} / \mathrm{E}$ & 16 & Møsvatn & 11881 & Mortåtjørni & & 1241 & 0.86 & 106073 & 6668293 & 0 & & 12.09 .84 & 5.40 & 0.48 & 42 \\
\hline $\mathrm{C} / \mathrm{E}$ & 16 & Møsvatn & 12073 & Grunnostjørni & & 1208 & 0.42 & 121236 & 6662626 & 0 & & 15.09 .83 & 6.20 & 1.19 & 42 \\
\hline $\mathrm{C} / \mathrm{E}$ & 16 & Møsvatn & 37 & Langesjå & & 1145 & 6.99 & 126347 & 6662765 & 0 & & 12.09 .84 & 6.80 & 1.31 & 42 \\
\hline $\mathrm{C} / \mathrm{E}$ & 16 & Møsvatn & 12040 & Reinarvatnet & & 1394 & 0.31 & 107009 & 6665028 & 0 & & 13.09 .83 & 5.19 & 0.78 & 89 \\
\hline $\mathrm{C} / \mathrm{E}$ & 16 & Møsvatn & 12146 & Tuddøltjørn & & 1237 & 0.63 & 116638 & 6661056 & 0 & & 13.09 .83 & 5.67 & 0.70 & 89 \\
\hline $\mathrm{C} / \mathrm{E}$ & 16 & Møsvatn & 12032 & Bukketjørn & & 1240 & 0.25 & 117722 & 6664058 & 0 & & 13.09 .83 & 6.05 & 0.71 & 89 \\
\hline $\mathrm{C} / \mathrm{E}$ & 16 & Møsvatn & 3 & Møsvatn & $\mathrm{x}$ & 919 & 78.77 & 114017 & 6655587 & 2 & 2 & 15.09 .83 & 5.90 & 0.84 & 3 \\
\hline $\mathrm{C} / \mathrm{E}$ & 16 & Møsvatn & 12178 & Landsetvatnet & & 1077 & 0.22 & 140859 & 6658142 & 1 & 0 & & & & 7 \\
\hline $\mathrm{C} / \mathrm{E}$ & 16 & Møsvatn & 12188 & Middøltjønne & & 1072 & 0.06 & 141341 & 6658117 & 1 & 0 & & & & 7 \\
\hline $\mathrm{C} / \mathrm{E}$ & 16 & Møsvatn & 12409 & Finnerottjørni & & 923 & 0.17 & 123664 & 6653003 & 1 & 1 & & & & 42 \\
\hline $\mathrm{C} / \mathrm{E}$ & 16 & Møsvatn & 12395 & Hondletjørni & & 924 & 0.24 & 123124 & 6652780 & 1 & 1 & & & & 42 \\
\hline $\mathrm{C} / \mathrm{E}$ & 17 & Mår/ Gøyst & 18698 & Sletteidvatni & & 1306 & 0.42 & 112017 & 6683971 & 0 & & 15.09 .83 & 5.60 & 0.65 & 42 \\
\hline $\mathrm{C} / \mathrm{E}$ & 17 & Mår/ Gøyst & 18661 & Sletteidvatni & & 1303 & 0.13 & 114440 & 6684637 & 0 & & 15.09 .83 & 5.80 & 0.51 & 42 \\
\hline $\mathrm{C} / \mathrm{E}$ & 17 & Mår/ Gøyst & 19131 & Vesle Saure & & 1147 & 0.99 & 113143 & 6673633 & 0 & & 12.09 .84 & 6.00 & 0.66 & 42 \\
\hline
\end{tabular}


Appendix I. Continued.

\begin{tabular}{|c|c|c|c|c|c|c|c|c|c|c|c|c|c|c|c|c|}
\hline 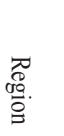 & & & 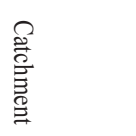 & 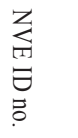 & 席 & 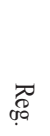 & 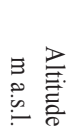 & 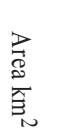 & & '? & 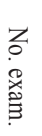 & 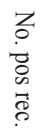 & $\underset{\stackrel{\overbrace{}}{*}}{\rightleftharpoons}$ & 茜 & 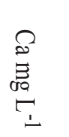 & 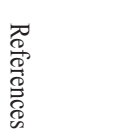 \\
\hline & & & & & & & & & $X$ & $\mathrm{Y}$ & & & & & & \\
\hline $\mathrm{C} / \mathrm{E}$ & 17 & & Mår/ Gøyst & 36649 & Haraldsjå & & 1080 & 1.02 & 131505 & 6671824 & 0 & & 15.09 .83 & 6.70 & 2.69 & 42 \\
\hline $\mathrm{C} / \mathrm{E}$ & 17 & & Mår/ Gøyst & 18642 & Viktjørn & & 1354 & 0.397 & 118551 & 6684136 & 0 & & 24.09 .95 & 6.02 & 0.44 & 88 \\
\hline $\mathrm{C} / \mathrm{E}$ & 17 & & Mår/ Gøyst & 19044 & Torstjørni & & 1220 & 0.378 & 109305 & 6676249 & 0 & & 21.09 .95 & 6.25 & 0.53 & 88 \\
\hline $\mathrm{C} / \mathrm{E}$ & 17 & & Mår/ Gøyst & 18679 & Sletteidvatni & & 1302 & 0.99 & 114495 & 6684111 & 0 & & 13.09 .83 & 5.76 & 0.55 & 89 \\
\hline $\mathrm{C} / \mathrm{E}$ & 17 & & Mår/ Gøyst & 18845 & Bakketjørn & & 1155 & 0.35 & 122801 & 6679611 & 0 & & 13.09 .83 & 6.05 & 0.84 & 89 \\
\hline $\mathrm{C} / \mathrm{E}$ & 17 & & Mår/ Gøyst & 18562 & Tangetjørnan & & 1261 & 0.232 & 101792 & 6687524 & 0 & & 21.09 .94 & 6.19 & 0.43 & 106 \\
\hline $\mathrm{C} / \mathrm{E}$ & 17 & & Mår/ Gøyst & 18132 & Austre Søltjørni & & 1197 & 0.599 & 128236 & 6692302 & 0 & & 21.09 .94 & 6.24 & 0.50 & 106 \\
\hline $\mathrm{C} / \mathrm{E}$ & 17 & & Mår/ Gøyst & 18187 & Vestre Søltjørni & & 1182 & 0.380 & 125474 & 6691715 & 0 & & 21.09 .94 & 6.29 & 0.56 & 106 \\
\hline $\mathrm{C} / \mathrm{E}$ & 17 & & Mår/ Gøyst & 17925 & Skjortetjørnan & & 1161 & 0.159 & 117274 & 6698507 & 0 & & 21.09 .94 & 6.50 & 1.66 & 106 \\
\hline $\mathrm{C} / \mathrm{E}$ & 17 & & Mår/ Gøyst & 18456 & Melrakktjørnane & & 1278 & 0.136 & 118023 & 6687392 & 0 & & 21.09 .94 & 6.55 & 1.33 & 106 \\
\hline $\mathrm{C} / \mathrm{E}$ & 17 & & Mår/ Gøyst & 18133 & Kosadalsvatnet & & 1136 & 0.551 & 116563 & 6693404 & 0 & & 21.09 .94 & 6.65 & 1.47 & 106 \\
\hline $\mathrm{C} / \mathrm{E}$ & 17 & & Mår/ Gøyst & 11868 & Torkjelstjørn & & 1168 & 0.07 & 136954 & 6666425 & 1 & 1 & & & & 3 \\
\hline $\mathrm{C} / \mathrm{E}$ & 17 & & Mår/ Gøyst & 92 & Rosjå & & 1174 & 2.03 & 134023 & 6680450 & 2 & 2 & 12.09 .84 & 6.80 & 2.41 & 3,7 \\
\hline $\mathrm{C} / \mathrm{E}$ & 17 & & Mår/ Gøyst & 18721 & Ljostjørn & & 1178 & 0.42 & 134529 & 6681268 & 1 & 1 & & & & 7 \\
\hline $\mathrm{C} / \mathrm{E}$ & 17 & & Mår/ Gøyst & 108 & Kalven & & 1294 & 1.35 & 110072 & 6689697 & 1 & 1 & 21.09 .94 & 6.09 & 0.42 & 66 \\
\hline $\mathrm{C} / \mathrm{E}$ & 17 & & Mår/ Gøyst & 104 & Hettefjorden & & 1228 & 2.33 & 113371 & 6691453 & 1 & 1 & 21.09 .94 & 6.39 & 0.74 & 66 \\
\hline $\mathrm{C} / \mathrm{E}$ & 17 & & Mår/ Gøyst & 96 & Eidsjoren & & 1229 & 2.05 & 110808 & 6693400 & 1 & 1 & 21.09 .94 & 6.44 & 0.90 & 66 \\
\hline $\mathrm{C} / \mathrm{E}$ & 17 & & Mår/ Gøyst & 103 & Reksjå & & 1207 & 2.81 & 119289 & 6681420 & 1 & 1 & 13.09 .83 & 5.68 & 0.75 & 74 \\
\hline $\mathrm{C} / \mathrm{E}$ & 17 & & Mår/ Gøyst & 93 & Vråsjåen & & 1115 & 2.68 & 113053 & 6676124 & 1 & 1 & 12.09 .84 & 6.10 & 0.64 & 74 \\
\hline $\mathrm{C} / \mathrm{E}$ & 17 & & Mår/ Gøyst & 109 & Viuvatnet & & 1324 & 3.03 & 109773 & 6687654 & 1 & 1 & 15.08 .00 & 6.12 & 0.47 & 74 \\
\hline $\mathrm{C} / \mathrm{E}$ & 17 & & Mår/ Gøyst & 94 & Kallungsjåen & & 1246 & 3.17 & 106784 & 6684434 & 1 & 1 & 02.10 .97 & 6.49 & 0.57 & 74 \\
\hline $\mathrm{C} / \mathrm{E}$ & 17 & & Mår/ Gøyst & 75 & Gøystvatnet & $\mathrm{x}$ & 1087 & 31.26 & 123821 & 6676361 & 5 & 3 & 15.09 .83 & 6.00 & 0.67 & $3,47,74$ \\
\hline $\mathrm{C} / \mathrm{E}$ & 17 & & Mår/ Gøyst & 36 & Mår & $\mathrm{x}$ & 1121 & 20.55 & 123922 & 6685973 & 10 & 4 & 12.09 .84 & 6.10 & 0.94 & $\begin{array}{l}3,9,47,74, \\
79\end{array}$ \\
\hline $\mathrm{C} / \mathrm{E}$ & 17 & & Mår/ Gøyst & 107 & Store Saure & & 1120 & 1.63 & 115955 & 6674870 & 2 & 1 & 15.09 .83 & 5.80 & 0.79 & 55,62 \\
\hline $\mathrm{C} / \mathrm{E}$ & 18 & A & Uvdalselvi & 17543 & Tjørngrøtjørnane & & 1195 & 0.046 & 133342 & 6710378 & 0 & & 29.10 .95 & 6.19 & 0.81 & 88 \\
\hline $\mathrm{C} / \mathrm{E}$ & 18 & A & Uvdalselvi & 17887 & Gråvårtjørn & & 1213 & 0.203 & 129358 & 6698072 & 0 & & 21.09 .94 & 5.98 & 0.42 & 106 \\
\hline $\mathrm{C} / \mathrm{E}$ & 18 & A & Uvdalselvi & 17823 & Langetjørni & & 1149 & 0.484 & 130951 & 6699604 & 0 & & 21.09 .94 & 6.08 & 0.54 & 106 \\
\hline $\mathrm{C} / \mathrm{E}$ & 18 & A & Uvdalselvi & 17796 & Fiskeløktjørni & & 1184 & 0.862 & 129576 & 6700826 & 0 & & 21.09 .94 & 6.27 & 0.66 & 106 \\
\hline $\mathrm{C} / \mathrm{E}$ & 18 & A & Uvdalselvi & 17790 & Kruketjørna & & 1137 & 0.167 & 131680 & 6700934 & 0 & & 21.09 .94 & 6.55 & 1.28 & 106 \\
\hline $\mathrm{C} / \mathrm{E}$ & 18 & A & Uvdalselvi & 17868 & Gryttjørni & & 1206 & 0.289 & 133127 & 6698172 & 0 & & 21.09 .94 & 6.76 & 1.88 & 106 \\
\hline $\mathrm{C} / \mathrm{E}$ & 18 & A & Uvdalselvi & 17773 & Bollatjørni & & 1181 & 0.72 & 126457 & 6701741 & 1 & 1 & 21.09 .94 & 6.61 & 1.37 & 3 \\
\hline $\mathrm{C} / \mathrm{E}$ & 18 & A & Uvdalselvi & 17828 & Hæratjønn & & 1249 & 0.07 & 135130 & 6699473 & 1 & 1 & & & & 3 \\
\hline $\mathrm{C} / \mathrm{E}$ & 18 & A & Uvdalselvi & 385 & Skarvsvatnet & & 1117 & 3.68 & 125273 & 6704599 & 2 & 2 & 21.09 .94 & 6.76 & 1.37 & 3,74 \\
\hline $\mathrm{C} / \mathrm{E}$ & 18 & A & Uvdalselvi & 411 & Tøddølvatnet & & 1101 & 1.29 & 129152 & 6706737 & 1 & 1 & 12.10 .97 & 7.20 & 4.82 & 74 \\
\hline $\mathrm{C} / \mathrm{E}$ & 18 & A & Uvdalselvi & 427 & Store Ormetjørni & & 1187 & 0.71 & 130989 & 6709879 & 5 & 5 & 21.09 .94 & 6.85 & 2.01 & $38,39,63$ \\
\hline $\mathrm{C} / \mathrm{E}$ & 18 & B & Uvdalselvi & 17848 & Øvre Halstjørnane & & 1190 & 0.105 & 122882 & 6699607 & 0 & & 29.10 .95 & 6.56 & 1.64 & 88 \\
\hline $\mathrm{C} / \mathrm{E}$ & 18 & B & Uvdalselvi & 17837 & Falkenuttjørnane & & 1271 & 0.127 & 127220 & 6699829 & 0 & & 21.09 .94 & 5.97 & 0.46 & 106 \\
\hline $\mathrm{C} / \mathrm{E}$ & 18 & B & Uvdalselvi & 18055 & $\begin{array}{l}\text { Nordre } \\
\text { Holstadtjørni }\end{array}$ & & 1198 & 0.281 & 124708 & 6694234 & 0 & & 21.09 .94 & 6.15 & 0.39 & 106 \\
\hline $\mathrm{C} / \mathrm{E}$ & 18 & B & Uvdalselvi & 18052 & Nedre Afdalstjørni & & 1102 & 0.265 & 131663 & 6693752 & 0 & & 21.09 .94 & 6.29 & 0.65 & 106 \\
\hline $\mathrm{C} / \mathrm{E}$ & 18 & B & Uvdalselvi & 18089 & Søre Holstadtjørni & & 1199 & 0.251 & 125832 & 6693465 & 0 & & 21.09 .94 & 6.32 & 0.62 & 106 \\
\hline $\mathrm{C} / \mathrm{E}$ & 18 & B & Uvdalselvi & 17935 & Dragøytjørni & & 1172 & 0.234 & 124531 & 6697263 & 0 & & 21.09 .94 & 6.35 & 0.90 & 106 \\
\hline $\mathrm{C} / \mathrm{E}$ & 18 & B & Uvdalselvi & 17867 & Halstjørn & & 1190 & 0.425 & 123493 & 6698934 & 0 & & 21.09 .94 & 6.54 & 1.20 & 106 \\
\hline $\mathrm{C} / \mathrm{E}$ & 18 & B & Uvdalselvi & 18264 & Store Gryttjørni & & 1234 & 0.391 & 137346 & 6688573 & 0 & & 21.09 .94 & 6.63 & 1.42 & 106 \\
\hline $\mathrm{C} / \mathrm{E}$ & 18 & B & Uvdalselvi & 18191 & $\begin{array}{l}\text { Nedre } \\
\text { Nutetjørnane }\end{array}$ & & 1217 & 0.194 & 134645 & 6690674 & 0 & & 21.09 .94 & 6.64 & 1.59 & 106 \\
\hline
\end{tabular}


Appendix I. Continued.

\begin{tabular}{|c|c|c|c|c|c|c|c|c|c|c|c|c|c|c|c|c|}
\hline 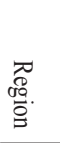 & & & 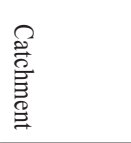 & $\begin{array}{l}z \\
z \\
\text { II } \\
\exists \\
z \\
\dot{z}\end{array}$ & $\stackrel{\overrightarrow{2}}{\overrightarrow{2}}$ & $\underset{\substack{\widetilde{0} \\
\text { co }}}{\overparen{0}}$ & 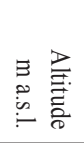 & 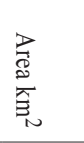 & & & 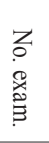 & 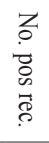 & $\begin{array}{l}\overrightarrow{\mathrm{o}} \\
\text { हैं }\end{array}$ & 草 & 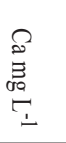 & 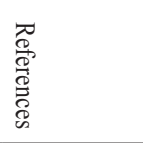 \\
\hline & & & & & & & & & $\mathrm{X}$ & $\mathrm{Y}$ & & & & & & \\
\hline $\mathrm{C} / \mathrm{E}$ & 18 & B & Uvdalselvi & 17810 & Mjågesjoren & & 1205 & 0.250 & 136935 & 6699369 & 0 & & 21.09 .94 & 6.95 & 2.78 & 106 \\
\hline $\mathrm{C} / \mathrm{E}$ & 18 & B & Ølmosåi & 410 & Smågefjorden & & 1172 & 2.37 & 126931 & 6695185 & 1 & 1 & 21.09 .94 & 6.33 & 0.58 & 74 \\
\hline $\mathrm{C} / \mathrm{E}$ & 18 & B & Ølmosåi & 17979 & Kvonneviertjørni & & 1103 & 0.11 & 131830 & 6695521 & 1 & 1 & & & & 74 \\
\hline $\mathrm{C} / \mathrm{E}$ & 18 & B & Ølmosåi & 426 & Damtjørn & & 1223 & 0.44 & 143306 & 6697950 & 1 & 0 & & & & 104 \\
\hline $\mathrm{C} / \mathrm{E}$ & 18 & B & Ølmosåi & 17949 & Sønstevatnet & $\mathrm{x}$ & 1060 & 12.53 & 142350 & 6693775 & 4 & 3 & 21.09 .94 & 6.55 & 1.27 & $63,74,104$ \\
\hline $\mathrm{C} / \mathrm{E}$ & 18 & B & Ølmosåi & 409 & Vikvatn & & 1064 & 1.22 & 133668 & 6694102 & 4 & 3 & 21.09 .94 & 6.68 & 1.45 & $\begin{array}{l}63,74,97, \\
104\end{array}$ \\
\hline $\mathrm{C} / \mathrm{E}$ & 19 & A & Lågen & 18274 & Øvre Bessvatnet & & 1313 & 0.06 & 76469 & 6694619 & 0 & & 17.07 .96 & 6.56 & 2.04 & 19 \\
\hline $\mathrm{C} / \mathrm{E}$ & 19 & A & Lågen & 18612 & Lakadalstjørnane & & 1285 & 0.14 & 81147 & 6688201 & 0 & & 31.07 .03 & 6.83 & 2.65 & 19 \\
\hline $\mathrm{C} / \mathrm{E}$ & 19 & A & Lågen & 18086 & Reinsmyrtjørni & & 1294 & 0.06 & 85109 & 6697360 & 0 & & 30.07 .98 & 6.84 & 2.90 & 19 \\
\hline $\mathrm{C} / \mathrm{E}$ & 19 & A & Lågen & 18445 & Vegarhovdtjørnan & & 1255 & 0.194 & 102718 & 6689092 & 0 & & 21.09 .95 & 6.20 & 0.52 & 88 \\
\hline $\mathrm{C} / \mathrm{E}$ & 19 & A & Lågen & 18211 & Feitfisktjørnan & & 1230 & 0.268 & 107376 & 6692928 & 0 & & 12.09 .97 & 6.37 & 0.55 & 88 \\
\hline $\mathrm{C} / \mathrm{E}$ & 19 & A & Lågen & 18536 & Langebutjørnan & & 1235 & 0.144 & 88840 & 6688873 & 0 & & 02.10 .97 & 6.44 & 2.03 & 88 \\
\hline $\mathrm{C} / \mathrm{E}$ & 19 & A & Lågen & 18076 & Torjustjørnan & & 1220 & 0.691 & 96849 & 6695359 & 0 & & 02.10 .97 & 6.74 & 2.03 & 88 \\
\hline $\mathrm{C} / \mathrm{E}$ & 19 & A & Lågen & 18478 & Lakadalstjørnane & & 1268 & 0.154 & 82119 & 6690318 & 0 & & 02.10 .97 & 6.82 & 3.95 & 88 \\
\hline $\mathrm{C} / \mathrm{E}$ & 19 & A & Lågen & 67633 & Andersosen & & 1308 & 0.124 & 76272 & 6705286 & 0 & & 09.10 .97 & 7.00 & 4.37 & 88 \\
\hline $\mathrm{C} / \mathrm{E}$ & 19 & A & Lågen & 17492 & Grønenuttjørnan & & 1180 & 0.096 & 111175 & 6714372 & 0 & & 12.10 .97 & 7.14 & 4.47 & 88 \\
\hline $\mathrm{C} / \mathrm{E}$ & 19 & A & Lågen & 17456 & Herbutjørnan & & 1183 & 0.180 & 114588 & 6715696 & 0 & & 12.10 .97 & 7.21 & 5.01 & 88 \\
\hline $\mathrm{C} / \mathrm{E}$ & 19 & A & Lågen & 18338 & Steintjørni & & 1307 & 0.874 & 105369 & 6690638 & 0 & & 21.09 .94 & 6.01 & 0.37 & 106 \\
\hline $\mathrm{C} / \mathrm{E}$ & 19 & A & Lågen & 18469 & Sørtjørn & & 1225 & 0.579 & 98746 & 6688587 & 0 & & 21.09 .94 & 6.21 & 0.51 & 106 \\
\hline $\mathrm{C} / \mathrm{E}$ & 19 & A & Lågen & 18239 & Bakketjørnan & & 1240 & 0.103 & 106117 & 6692561 & 0 & & 21.09 .94 & 6.30 & 0.83 & 106 \\
\hline $\mathrm{C} / \mathrm{E}$ & 19 & A & Lågen & 18199 & Nottartjørni & & 1223 & 0.543 & 98972 & 6693651 & 0 & & 21.09 .94 & 6.35 & 1.04 & 106 \\
\hline $\mathrm{C} / \mathrm{E}$ & 19 & A & Lågen & 17653 & Nordskarvet & & 1123 & 1.702 & 120711 & 6706344 & 0 & & 21.09 .94 & 6.39 & 1.00 & 106 \\
\hline $\mathrm{C} / \mathrm{E}$ & 19 & A & Lågen & 18466 & Langebu-tjørnan & & 1246 & 0.466 & 87396 & 6688826 & 0 & & 21.09 .94 & 6.44 & 1.11 & 106 \\
\hline $\mathrm{C} / \mathrm{E}$ & 19 & A & Lågen & 18096 & Veisetjørnan & & 1237 & 0.213 & 94612 & 6695944 & 0 & & 21.09 .94 & 6.55 & 1.32 & 106 \\
\hline $\mathrm{C} / \mathrm{E}$ & 19 & A & Lågen & 17565 & Lometjørni & & 1225 & 0.278 & 99207 & 6712469 & 0 & & 21.09 .94 & 6.57 & 1.06 & 106 \\
\hline $\mathrm{C} / \mathrm{E}$ & 19 & A & Lågen & 17999 & Lomavikan & & 1210 & 0.209 & 95448 & 6698337 & 0 & & 21.09 .94 & 6.57 & 1.44 & 106 \\
\hline $\mathrm{C} / \mathrm{E}$ & 19 & A & Lågen & 18050 & Torjustjørnan & & 1220 & 0.627 & 98330 & 6696625 & 0 & & 21.09 .94 & 6.59 & 1.61 & 106 \\
\hline $\mathrm{C} / \mathrm{E}$ & 19 & A & Lågen & 276916 & Danemannstjønni & & 1166 & 0.255 & 110914 & 6701192 & 0 & & 21.09 .94 & 6.63 & 1.46 & 106 \\
\hline $\mathrm{C} / \mathrm{E}$ & 19 & A & Lågen & 17332 & Båtstjørni & & 1157 & 0.711 & 102267 & 6721178 & 0 & & 21.09 .94 & 6.66 & 1.47 & 106 \\
\hline $\mathrm{C} / \mathrm{E}$ & 19 & A & Lågen & 17981 & Brutjørnan & & 1220 & 0.587 & 93030 & 6698601 & 0 & & 21.09 .94 & 6.68 & 1.52 & 106 \\
\hline $\mathrm{C} / \mathrm{E}$ & 19 & A & Lågen & 17624 & Skaupsjøtjørnan & & 1157 & 0.340 & 100267 & 6710074 & 0 & & 21.09 .94 & 6.68 & 1.97 & 106 \\
\hline $\mathrm{C} / \mathrm{E}$ & 19 & A & Lågen & 17800 & Dagfisketjørni & & 1167 & 0.878 & 112359 & 6701694 & 0 & & 21.09 .94 & 6.72 & 1.71 & 106 \\
\hline $\mathrm{C} / \mathrm{E}$ & 19 & A & Lågen & 18023 & Storfisktjørni & & 1235 & 1.127 & 90270 & 6697238 & 0 & & 21.09 .94 & 6.77 & 2.17 & 106 \\
\hline $\mathrm{C} / \mathrm{E}$ & 19 & A & Lågen & 17685 & Kalvetjørnan & & 1170 & 0.058 & 99694 & 6708108 & 0 & & 21.09 .94 & 6.84 & 2.40 & 106 \\
\hline $\mathrm{C} / \mathrm{E}$ & 19 & A & Lågen & 17460 & Orsjøtjørni & & 1079 & 0.43 & 122190 & 6714827 & 1 & 1 & 21.09 .94 & 6.80 & 1.88 & 2 \\
\hline $\mathrm{C} / \mathrm{E}$ & 19 & A & Lågen & 17591 & Halstjørni & & 1022 & 0.08 & 119782 & 6710045 & 1 & 1 & & & & 2 \\
\hline $\mathrm{C} / \mathrm{E}$ & 19 & A & Lågen & 17612 & Vesle Selstjørni & & 1128 & 0.10 & 109866 & 6710191 & 1 & 1 & & & & 2 \\
\hline $\mathrm{C} / \mathrm{E}$ & 19 & A & Lågen & 17807 & Austre Bakkatjørn & & 1213 & 0.60 & 94866 & 6703502 & 1 & 1 & 21.09 .94 & 6.60 & 1.77 & 3 \\
\hline $\mathrm{C} / \mathrm{E}$ & 19 & A & Lågen & 66954 & Hølen & & 1157 & 0.47 & 113891 & 6703571 & 2 & 2 & 21.09 .94 & 6.55 & 1.31 & 16 \\
\hline $\mathrm{C} / \mathrm{E}$ & 19 & A & Lågen & 417 & Krossvatnet & & 1165 & 1.69 & 111939 & 6699586 & 2 & 2 & 21.09 .94 & 6.59 & 1.29 & 16,74 \\
\hline $\mathrm{C} / \mathrm{E}$ & 19 & A & Lågen & 18290 & Høgevardetjørn & & 1357 & 0.23 & 74515 & 6693954 & 1 & 1 & 17.07 .96 & 6.32 & 2.13 & 19 \\
\hline $\mathrm{C} / \mathrm{E}$ & 19 & A & Lågen & 18650 & Holbergtjørnane & & 1314 & 0.21 & 82385 & 6687575 & 1 & 1 & 31.07 .03 & 6.93 & 1.90 & 19 \\
\hline $\mathrm{C} / \mathrm{E}$ & 19 & A & Lågen & 18257 & Bessvatnet & & 1303 & 0.30 & 77497 & 6694635 & 1 & 1 & 02.10 .97 & 7.07 & 2.84 & 67 \\
\hline $\mathrm{C} / \mathrm{E}$ & 19 & A & Lågen & 18336 & Dimmedalstjørni & & 1325 & 0.16 & 76839 & 6692957 & 1 & 1 & & 5.90 & & 67 \\
\hline $\mathrm{C} / \mathrm{E}$ & 19 & A & Lågen & 17411 & Hetjørni & & 1162 & 0.22 & 96712 & 6718971 & 1 & 0 & & & & 67 \\
\hline
\end{tabular}


Appendix I. Continued.

\begin{tabular}{|c|c|c|c|c|c|c|c|c|c|c|c|c|c|c|c|c|}
\hline 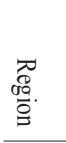 & & & 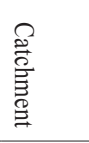 & $\begin{array}{l}z \\
\text { r1 } \\
\exists \\
\Xi \\
\vdots\end{array}$ & $\overrightarrow{\vec{\partial}}$ & 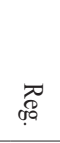 & 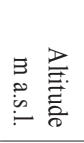 & $\begin{array}{l}\vec{P} \\
\mathbb{D} \\
\hat{W}_{N}\end{array}$ & & م. & $\begin{array}{l}z \\
0 \\
0 \\
\dot{x} \\
\hat{\tilde{O}}\end{array}$ & $\begin{array}{l}z \\
\dot{0} \\
\dot{c} \\
0 \\
\overrightarrow{0} \\
?\end{array}$ & $\begin{array}{l}\text { Ð } \\
\text { हैं }\end{array}$ & 茫 & 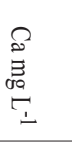 & 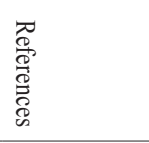 \\
\hline & & & & & & & & & $\mathrm{X}$ & $\mathrm{Y}$ & & & & & & \\
\hline $\mathrm{C} / \mathrm{E}$ & 19 & $\mathrm{~A}$ & Lågen & 17959 & Holmavatn & & 1260 & 0.10 & 80443 & 6700892 & 1 & 1 & & & & 67 \\
\hline $\mathrm{C} / \mathrm{E}$ & 19 & A & Lågen & 18289 & X-tjørn & & 1326 & 0.04 & 75897 & 6694381 & 1 & 1 & & & & 71 \\
\hline $\mathrm{C} / \mathrm{E}$ & 19 & A & Lågen & 18305 & Y-tjørn & & 1330 & 0.04 & 75917 & 6693986 & 1 & 1 & & & & 71 \\
\hline $\mathrm{C} / \mathrm{E}$ & 19 & A & Lågen & 17843 & Vestre Bakketjørn & & 1211 & 1.63 & 93717 & 6702002 & 1 & 1 & 21.09 .94 & 6.35 & 1.10 & 74 \\
\hline $\mathrm{C} / \mathrm{E}$ & 19 & A & Lågen & 17750 & Holmetjørnane & & 1207 & 0.77 & 97434 & 6705361 & 1 & 1 & & & & 74 \\
\hline $\mathrm{C} / \mathrm{E}$ & 19 & A & Lågen & 17357 & Hytetjørne & & 1193 & 0.06 & 115119 & 6719447 & 1 & 1 & & & & 74 \\
\hline $\mathrm{C} / \mathrm{E}$ & 19 & A & Lågen & 18193 & Melrakktjørni & & 1211 & 0.50 & 102715 & 6693467 & 1 & 1 & & & & 74 \\
\hline $\mathrm{C} / \mathrm{E}$ & 19 & A & Lågen & 18225 & $\begin{array}{l}\text { Nordre } \\
\text { Skjærhøltjørn }\end{array}$ & & 1218 & 0.44 & 100813 & 6693069 & 1 & 1 & & & & 74 \\
\hline $\mathrm{C} / \mathrm{E}$ & 19 & A & Lågen & 17895 & Reinavatnet & & 1173 & 0.53 & 109940 & 6699644 & 1 & 1 & & & & 74 \\
\hline $\mathrm{C} / \mathrm{E}$ & 19 & A & Lågen & 17965 & Skrovstjørni & & 1222 & 0.13 & 92249 & 6699618 & 1 & 1 & & & & 74 \\
\hline $\mathrm{C} / \mathrm{E}$ & 19 & A & Lågen & 17988 & Tjuvhyttjørni & & 1182 & 0.24 & 107380 & 6697413 & 1 & 1 & & & & 74 \\
\hline $\mathrm{C} / \mathrm{E}$ & 19 & A & Lågen & 279619 & Vestre Bakketjørn & & 1212 & 1.29 & 93573 & 6702169 & 1 & 1 & & & & 74 \\
\hline $\mathrm{C} / \mathrm{E}$ & 19 & A & Lågen & 392 & Storekrekkja & & 1151 & 4.18 & 101435 & 6723196 & 1 & 1 & 21.09 .94 & 6.09 & 0.48 & 105 \\
\hline $\mathrm{C} / \mathrm{E}$ & 19 & A & Lågen & 17584 & Skaupungen & & 1150 & 0.17 & 102161 & 6711896 & 1 & 1 & & & 1.76 & 112 \\
\hline $\mathrm{C} / \mathrm{E}$ & 19 & A & Lågen & 415 & Halnefjorden & $\mathrm{x}$ & 1130 & 13.70 & 101185 & 6715697 & 16 & 16 & 21.09 .94 & 6.72 & 1.81 & $\begin{array}{l}1,2,3,44 \\
61,83,96 \\
105,112\end{array}$ \\
\hline $\mathrm{C} / \mathrm{E}$ & 19 & A & Lågen & 17040 & Svartevatnet & & 1233 & 1.13 & 99538 & 6728768 & 14 & 7 & 25.07 .93 & 5.69 & 0.35 & $\begin{array}{l}10,33,35 \\
67,107\end{array}$ \\
\hline $\mathrm{C} / \mathrm{E}$ & 19 & A & Lågen & 17343 & Breidvatnet & & 1162 & 1.00 & 118578 & 6719115 & 4 & 4 & & & & $16,17,18,74$ \\
\hline $\mathrm{C} / \mathrm{E}$ & 19 & A & Lågen & 17364 & Korta & & 1163 & 0.26 & 117084 & 6718774 & 4 & 4 & & & & $16,17,74$ \\
\hline $\mathrm{C} / \mathrm{E}$ & 19 & A & Lågen & 396 & Geitvatnet & & 1197 & 1.55 & 105307 & 6695177 & 4 & 4 & 21.09 .94 & 6.52 & 1.18 & $16,21,27,74$ \\
\hline $\mathrm{C} / \mathrm{E}$ & 19 & A & Lågen & 18374 & Bismarvatnet & & 1331 & 1.88 & 74729 & 6692150 & 6 & 3 & & 6.00 & & $19,67,70,74$ \\
\hline $\mathrm{C} / \mathrm{E}$ & 19 & $\mathrm{~A}$ & Lågen & 17397 & Heinungen & & 1138 & 0.37 & 105066 & 6718724 & 3 & 1 & 21.09 .94 & 6.34 & 0.80 & 2,105 \\
\hline $\mathrm{C} / \mathrm{E}$ & 19 & A & Lågen & 390 & Orsjoren & & 951 & 2.37 & 125791 & 6712627 & 5 & 5 & 21.09 .94 & 6.73 & 1.57 & $2,15,17,103$ \\
\hline $\mathrm{C} / \mathrm{E}$ & 19 & A & Lågen & 17454 & Bjordalsvatn & & 1121 & 0.52 & 118134 & 6715599 & 2 & 2 & 21.09 .94 & 6.97 & 3.12 & 2,3 \\
\hline $\mathrm{C} / \mathrm{E}$ & 19 & A & Lågen & 414 & Øvre Hein & & 1113 & 6.33 & 106335 & 6714906 & 6 & 6 & 21.09 .94 & 6.56 & 1.11 & $\begin{array}{l}2,3, \quad 105, \\
112\end{array}$ \\
\hline $\mathrm{C} / \mathrm{E}$ & 19 & A & Lågen & 66935 & Heintjønne & & 1112 & 0.58 & 109162 & 6712787 & 3 & 3 & 17.07 .67 & 6.60 & 0.80 & $2,3,112$ \\
\hline $\mathrm{C} / \mathrm{E}$ & 19 & A & Lågen & 394 & Geitsjøen & & 1112 & 3.22 & 113050 & 6706544 & 6 & 6 & 22.07 .67 & 6.90 & 1.32 & $\begin{array}{l}2,3,16,17, \\
112\end{array}$ \\
\hline $\mathrm{C} / \mathrm{E}$ & 19 & A & Lågen & 416 & Skrykken & & 1158 & 5.09 & 116530 & 6700686 & 6 & 6 & 21.09 .94 & 6.51 & 1.30 & $2,3,16,74$ \\
\hline $\mathrm{C} / \mathrm{E}$ & 19 & A & Lågen & 17583 & Nedre Hein & & 1075 & 1.23 & 113349 & 6710330 & 8 & 8 & 26.07 .92 & 6.61 & 1.50 & $\begin{array}{l}2,3,44,74 \\
105,112\end{array}$ \\
\hline $\mathrm{C} / \mathrm{E}$ & 19 & A & Lågen & 391 & Veslekrækkja & & 1148 & 1.98 & 103447 & 6720601 & 4 & 2 & 21.09 .94 & 6.27 & 0.64 & $\begin{array}{l}2,44,105, \\
112\end{array}$ \\
\hline $\mathrm{C} / \mathrm{E}$ & 19 & A & Lågen & 17366 & Nedre Bjørkevatn & & 1161 & 0.84 & 120435 & 6717924 & 5 & 5 & 21.09 .94 & 6.84 & 2.13 & 2,74 \\
\hline $\mathrm{C} / \mathrm{E}$ & 19 & A & Lågen & 17617 & Store Selstjørni & & 1135 & 0.49 & 107988 & 6709350 & 3 & 3 & 21.09 .94 & 6.96 & 2.96 & $2,74,112$ \\
\hline $\mathrm{C} / \mathrm{E}$ & 19 & A & Lågen & 17318 & Langetjørni & & 1201 & 0.31 & 114730 & 6720445 & 4 & 4 & & & & $3,16,17$ \\
\hline $\mathrm{C} / \mathrm{E}$ & 19 & A & Lågen & 420 & Nordmannslågen & & 1244 & 10.88 & 79991 & 6697139 & 9 & 9 & 30.07 .98 & 6.87 & 2.40 & $\begin{array}{l}3,16,67,71 \\
74\end{array}$ \\
\hline $\mathrm{C} / \mathrm{E}$ & 19 & A & Lågen & 18253 & Skjærhøl & & 1216 & 0.94 & 101092 & 6691921 & 3 & 3 & & & & $3,16,74$ \\
\hline $\mathrm{C} / \mathrm{E}$ & 19 & A & Lågen & 428 & Skaupsjøen & & 1155 & 2.95 & 96915 & 6712322 & 4 & 4 & 21.09 .94 & 6.85 & 2.59 & $3,16,74,101$ \\
\hline $\mathrm{C} / \mathrm{E}$ & 19 & $\mathrm{~A}$ & Lågen & 17477 & Skiftesjøen & & 1236 & 0.82 & 90493 & 6716874 & 9 & 9 & & & & $3,35,74$ \\
\hline $\mathrm{C} / \mathrm{E}$ & 19 & A & Lågen & 395 & Langesjøen & & 1210 & 11.04 & 97530 & 6698934 & 7 & 7 & 29.10 .95 & 6.61 & 1.56 & $\begin{array}{l}3,4,16,17 \\
72,95,102\end{array}$ \\
\hline $\mathrm{C} / \mathrm{E}$ & 19 & A & Lågen & 418 & Bjornesfjorden & & 1223 & 18.38 & 93966 & 6692522 & 8 & 8 & 21.09 .94 & 6.55 & 1.38 & $\begin{array}{l}3,4,5,6,16 \\
74,102\end{array}$ \\
\hline
\end{tabular}


Appendix I. Continued.

\begin{tabular}{|c|c|c|c|c|c|c|c|c|c|c|c|c|c|c|c|c|}
\hline 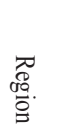 & & & 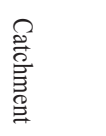 & 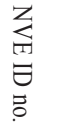 & Е & 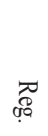 & 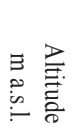 & $\begin{array}{l}\underset{D}{P} \\
\stackrel{D}{D} \\
\mathbb{K}_{N}\end{array}$ & & 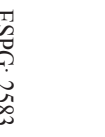 & $\begin{array}{l}\text { Z } \\
0 \\
0 \\
x \\
0 \\
0\end{array}$ & 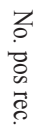 & $\underset{\stackrel{\overbrace{}}{\vec{*}}}{\nabla}$ & 矛 & $\stackrel{2}{\stackrel{0}{\Xi}}$ & 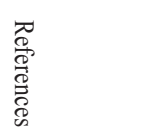 \\
\hline & & & & & & & & & $X$ & $\mathrm{Y}$ & & & & & & \\
\hline $\mathrm{C} / \mathrm{E}$ & 19 & $\mathrm{~A}$ & Lågen & 419 & Lakjen & & 1243 & 3.12 & 85395 & 6693471 & 3 & 3 & 02.10 .97 & 6.93 & 3.03 & $3,67,71$ \\
\hline $\mathrm{C} / \mathrm{E}$ & 19 & A & Lågen & 17826 & Flotatjørni & & 1209 & 0.77 & 102363 & 6702249 & 3 & 3 & 21.09 .94 & 6.76 & 2.03 & 3,72 \\
\hline $\mathrm{C} / \mathrm{E}$ & 19 & A & Lågen & 17908 & Langesjøtjørni & & 1209 & 0.26 & 105566 & 6699604 & 6 & 6 & 21.09 .94 & 6.66 & 1.74 & 3,72 \\
\hline $\mathrm{C} / \mathrm{E}$ & 19 & A & Lågen & 17018 & Svartevasstjørni & & 1237 & 0.40 & 99168 & 6730136 & 15 & 4 & 25.07 .93 & 5.74 & 0.28 & $\begin{array}{l}33,35,36 \\
37,107\end{array}$ \\
\hline $\mathrm{C} / \mathrm{E}$ & 19 & A & Lågen & 17746 & Stigstuvtjørni & & 1212 & 0.06 & 94207 & 6705959 & 2 & 2 & & & & 34,74 \\
\hline $\mathrm{C} / \mathrm{E}$ & 19 & A & Lågen & 393 & Dragøyfjorden & & 1180 & 3.33 & 98419 & 6725710 & 21 & 18 & 31.05 .93 & 5.49 & 0.65 & $\begin{array}{l}\text { 67, 111, own } \\
\text { data }\end{array}$ \\
\hline $\mathrm{C} / \mathrm{E}$ & 19 & A & Lågen & 421 & Dimmedalsvatnet & & 1334 & 1.70 & 75845 & 6690862 & 5 & 5 & 11.07 .78 & 6.80 & 2.53 & $\begin{array}{l}67,70,74, \\
114\end{array}$ \\
\hline $\mathrm{C} / \mathrm{E}$ & 19 & A & Lågen & 18208 & Gravagjelstjønn & & 1346 & 0.21 & 75958 & 6695803 & 2 & 1 & 24.07 .01 & 6.65 & 2.85 & 67,71 \\
\hline $\mathrm{C} / \mathrm{E}$ & 19 & A & Lågen & 17898 & Nordvatnet & & 1256 & 1.02 & 78918 & 6701916 & 3 & 3 & 29.10 .95 & 6.52 & 3.30 & $67,71,74$ \\
\hline $\mathrm{C} / \mathrm{E}$ & 19 & A & Lågen & 18164 & $\begin{array}{l}\text { Øvre } \\
\text { Krakavadtjørni }\end{array}$ & & 1225 & 0.74 & 89462 & 6695153 & 2 & 2 & & & & 74 \\
\hline $\mathrm{C} / \mathrm{E}$ & 19 & A & Lågen & 17899 & $\begin{array}{l}\text { Kleivshovd- } \\
\text { tjørnane }\end{array}$ & & 1214 & 0.44 & 92044 & 6700797 & 1 & 1 & 21.09 .94 & 6.51 & 1.20 & 74 \\
\hline $\mathrm{C} / \mathrm{E}$ & 19 & $\mathrm{~B}$ & Ufysja & 17222 & Tindevatnet & & 1265 & 0.192 & 121472 & 6722322 & 0 & & 21.09 .94 & 6.62 & 3.52 & 106 \\
\hline $\mathrm{C} / \mathrm{E}$ & 19 & $\mathrm{~B}$ & Ufysja & 17297 & Svantjern & & 1129 & 0.21 & 124886 & 6719724 & 1 & 1 & & & & 2 \\
\hline $\mathrm{C} / \mathrm{E}$ & 19 & $\mathrm{~B}$ & Ufysja & 17244 & Tuvetjørni & & 1236 & 0.20 & 117562 & 6722207 & 4 & 4 & 21.09 .94 & 6.90 & 2.47 & 16 \\
\hline $\mathrm{C} / \mathrm{E}$ & 19 & B & Ufysja & 17432 & Usgrimsvatni & & 1213 & 0.15 & 127748 & 6715609 & 1 & 1 & & & & 74 \\
\hline $\mathrm{C} / \mathrm{E}$ & 19 & $\mathrm{~B}$ & Ufysja & 17401 & Ljosevatnet & & 1182 & 0.90 & 125104 & 6716355 & 5 & 5 & 21.09 .94 & 6.79 & 1.83 & $2,16,74$ \\
\hline $\mathrm{C} / \mathrm{E}$ & 19 & B & Ufysja & 17281 & Holværvatnet & & 1183 & 1.43 & 119750 & 6720539 & 4 & 4 & 21.09 .94 & 7.11 & 3.31 & $2,17,74$ \\
\hline $\mathrm{C} / \mathrm{E}$ & 20 & & Ørteråni & 17104 & Øvre Trestiklan & $\mathrm{x}$ & 1149 & 0.48 & 103479 & 6727779 & 3 & 1 & 28.08 .05 & 6.43 & 0.70 & $22,23,24$ \\
\hline $\mathrm{C} / \mathrm{E}$ & 20 & & Ørteråni & 17371 & Skjerjavatnet & & 1192 & 1.57 & 113282 & 6718885 & 10 & 9 & & & & $\begin{array}{l}28,29,30 \\
31,32,69 \\
74,83,91\end{array}$ \\
\hline $\mathrm{C} / \mathrm{E}$ & 20 & & Ørteråni & 553 & Ørteren & $\mathrm{x}$ & 1147 & 9.44 & 103584 & 6725146 & 10 & 5 & 26.08 .05 & 6.53 & 1.80 & $\begin{array}{l}3,22,23,25 \\
26,74,78\end{array}$ \\
\hline $\mathrm{C} / \mathrm{E}$ & 20 & & Ørteråni & 67975 & Lægreidvatnet & $\mathrm{x}$ & 1147 & 1.74 & 106124 & 6723166 & 5 & 4 & 23.08 .05 & 6.77 & 2.30 & $\begin{array}{l}3, \quad 22, \quad 23 \\
74,78\end{array}$ \\
\hline $\mathrm{C} / \mathrm{E}$ & 20 & & Ørteråni & 17395 & Grønevatnet & & 1190 & 1.21 & 111304 & 6718009 & 2 & 2 & & & & 3,74 \\
\hline
\end{tabular}

\section{REFERENCES}

1 Aass P. 1969. Crustacea, especially Lepidurus arcticus Pallas, as brown trout food in Norwegian mountain reservoirs. Institute of Freshwater Research, Drottningholm. Report No 49, 1969: 183 - 201.

2 Amundsen T. 1976. Fiskeribiologiske undersøkelser for Dagalivassdraget 1974-75. Fiskerikonsulenten for Øst-Norge. Rapport Na IV-3.2. 285pp. (In Norwegian).

3 Norwegian Biodiversity Information Center, Artsdatabanken.no

4 Barlaup BT, Kleiven E, Skoglund H. 2002. Fiskebiologiske undersøkelser i Langesjøen, august 2001. Laboratoriet for ferskvannsøkologi og innlandsfiske (LFI), Universitetet i Bergen. Rapport nr. 120-2002. 39pp. (In Norwegian).

5 Barlaup BT, Sandven OR, Skoglund H, Gabrielsen S-E, Wiers T, Kleiven E, Lehmann G, Fjellheim A, Halvorsen GA, Hobæk A, Tysse Å. 2008. Restaurering av gyteområder og prøvefiske i Bjornesfjorden 1999-2007. Laboratoriet for ferskvannsøkologi og innlandsfiske (LFI), Universitetet i Bergen. Rapport nr. 150-2008. 70pp. (In Norwegian).

6 Barlaup BT, Gabrielsen S-E, Skoglund H, Wiers T, Halvorsen GA, Hobæk A, Lehman GB, Pulg U, Skår B, Normann E, Fjellheim A. 2014. Bjornesfjorden - Restaurering av gyteområder og fiskeribiologiske undersøkelser i perioden 1999-2013. LFI Uni Research Miljø, LFI Rapport nr. 235. 60pp. (In Norwegian).

7 Bjørtuft SK, Saltveit SJ. 1993. Fiskeribiologiske undersøkelser i forbindelse med planlagte overføringer til Mår kraftverk i Telemark. Laboratoriet for ferskvannsøkologi og innlandsfiske (LFI), Universitetet i Oslo. Rapport nr. 140-1993. 33pp. (In Norwegian).

8 Borgstrøm R, Sporan NR. 1998. Prøvefiske i Ambjørnsvatn, Ullensvang Statsallmenning, i 1997. Bestandsanalyse og forslag til driftsplan. Norges landbrukshøgskole, Institutt for biologi og naturforvaltning. Fiskerapport nr. 8-1998. 17pp. (In Norwegian).

9 Borgstrøm R. 1973. The effect of increased level fluctuation upon the brown trout population of Mårvatn, a Norwegian reservoir. Norwegian Journal of Zoologi 21: $101-112$.

10 Borgstrøm R. 1990. Aurebetanden i Svartavasstjønn. Notat. (In Norwegian).

11 Borgstrøm R. 2014. Aurebestandane i Litlosvatn og Kollsvatn i Kvennavassdraget på Hardangervidda. Norges miljø- og biovitenskapelige 
universitet, Institutt for naturforvaltning. INA fagrapport 28. 24pp. (In Norwegian).

12 Borgstrøm R, Brabrand Å, Solheim JT. 1986. Tilslamming og redusert siktedyp i Ringedalsmagasinet: Virkning på habitatbruk, næringsopptak og kondisjon hos pelagisk aure. Laboratoriet for ferskvannsøkologi og innlandsfiske (LFI), Universitetet i Oslo. Rapport nr. 90-1986. 36pp. (In Norwegian).

13 Borgstrøm R, Dokk JG, Heun M, Thaulow J. 2010. Aurebestandar i Vierslaområdet. Universitetet for miljø- og biovitenskap, Institutt for naturforvaltning. Fagrapport Fiskeforvaltning i høgfjellet nr. 3-2010. 10pp. (In Norwegian).

14 Brabrand, A.. 2007. Virkning av lav sommervannstand på fisk i reguleringsmagasiner. Laboratorium for ferskvannsøkologi og innlandsfiske (LFI), Universitetet i Oslo. Rapport nr. 249-2007. 54pp. (In Norwegian).

15 Dahl K, Sømme ID. 1933. Fisket i Dagali sameie. Norges Jæger- og Fiskerforenings Tidsskrift: 297 - 301. (In Norwegian).

16 Dahl K. 1915. En studie over grundaatens eller matfloens (Gammarus pulex) biologi og utbredelse i Norge. Særtrykk av Norges Jæger- og Fiskerforenings Tidsskrift 1915. 32pp. (In Norwegian).

17 Dahl K. 1917. Studier og forsøk over Ørret og Ørretvand. Kristiania. Det Mallingske Bogtrykkeri. (In Norwegian).

18 Dahl K. 1920. Studier over røje i ørretvand. Norges Jæger- og Fiskerforenings Tidsskrift 1920: 233 - 248. (In Norwegian).

19 Eidfjord fjellstyre 1995-2010. Diverse fiskerapporter. www.eidfjord-fjellstyre.no (In Norwegian).

20 Elnan G. 2000. Prøvefiskerapport frå Tinnhølen, 02.08.2000. Eidfjord fjellstyre. 2pp. (In Norwegian).

21 Enerud J, Garnås E. 1987. Fiskeribiologiske undersøkelser i Geitvatnet, Nore og Uvdal kommune, Buskerud fylke. Fylkesmannen i Buskerud, miljøvernavdelingen. Rapport nr. F-1, 1987. 17pp. (In Norwegian).

22 Enerud J, Garnås E. 1995. Fiskeribiologiske undersøkelser i Ørteren, Lægreidvatn, Øvre og Nedre Trestiklan, Hol kommune 1994. Fylkesmannen i Buskerud, miljøvernavdelingen. Rapport nr. 14-1995. 33pp. (In Norwegian).

23 Enerud J. 2006. Fiskeribiologiske undersøkelser i Ørteren, Lægreidvatn, Øvre og Nedre Trestiklan, Hol kommune 2005. Fisk- og miljøundersøkelser. Rapport. 36pp. (In Norwegian).

24 Eriksen SD, Garnås E. 1986a. Prøvefiske og driftsplan for Øvre Trestiklan 1986. Prosjekt Fjellfisk, rapport nr.19/86. 9pp. (In Norwegian).

25 Eriksen SD, Garnås E. 1986b. Prøvefiske og driftsplan for Nedre Trestiklan 1986. Prosjekt Fjellfisk, rapport nr.20/86. 8pp. (In Norwegian).

26 Eriksen SD, Garnås E. 1987. Prøvefiske og driftsplan for Ørteren 1987. Prosjekt Fjellfisk, rapport nr.91/87. 8pp. (In Norwegian).

27 Eriksen SD, Garnås E. 1988. Prøvefiske og driftsplan for Geitvatn 1988. Prosjekt Fjellfisk, rapport nr.147/88. 8pp. (In Norwegian).

28 Eriksen SD. 1985. Prøvefiske og driftsplan for Skjerja 1985. Hol kommune. Rapport. 13pp. (In Norwegian).

29 Eriksen SD. 1988. Prøvefiske og driftsplan for Skjerja 1988. Prosjekt Fjellfisk, rapport nr.121/88. 9pp. (In Norwegian).

30 Eriksen SD. 1991. Prøvefiske og driftsplan for Skjerja 1991. Prosjekt Fjellfisk, rapport nr.232/91. 8pp. (In Norwegian).

31 Eriksen SD. 1992. Prøvefiske og driftsplan for Skjerja 1992. Hol kommune, rapport nr. 2/92. 18pp. (In Norwegian).

32 Eriksen SD. 1995. Prøvefiske og driftsplan for Skjerja 1995. Hol kommune, rapport nr. 9/95. 11pp. (In Norwegian).

33 Fjellheim A, Tysse Å. 2011. Finprikkauren på Hardangervidda. Årsrapport 2010. LFI Uni Miljø. Notat. 15pp. (In Norwegian).

34 Fjellheim A. 2004. Virkning av rotenonbehandling på bunndyrsamfunnene i et område ved Stigstu, Hardangervidda. Lab. Ferskv. Økol. Innlandsfiske. LFI-UNIFOB. Universitetet i Bergen. Rapport nr. 122. $60 \mathrm{~s}$.

35 Fjellheim A, Tysse Å, Bjerknes V, Wright RF. 2002. Finprikkauren på Hardangervidda. DN-utredning 2002-1. 58pp. (In Norwegian).

36 Fjellheim A, Tysse Å, Bjerknes V, Elnan G, Gåsdal O, Stakseng H. 2007. Finprikkauren på Hardangervidda 1997-2006. LFI-UNIFOB. Rapport nr. 142. 63pp. (In Norwegian).

37 Fjellheim A, Tysse Å, Elnan G, Gåsdal O, Stakseng H. 2008. Finprikkauren på Hardangervidda. Statusrapport 2007. LFI-UNIFOB. Notat. 14pp. (In Norwegian).

38 Garnås E, Enerud J. 1996. Fiskeribiologiske undersøkelser i Ormetjern, Nore og Uvdal kommune, 1994. Fylkesmannen i Buskerud, miljøvernavdelingen. Rapport nr. 13-1996. 21pp. (In Norwegian).

39 Garnås E, Huseby K. 1995. Prosjekt Fjellfisk. Et prosjekt for bedre utnyttelse av innlandsfiskeressurser. Sluttrapport 1986-1992. 34pp. (In Norwegian).

40 Gjelsvik L. 1999. Størrelse og pigmentering hos Daphnia longispina i forhold til tettheten av ørret, Salmo trutta L., i innsjøer på Hardangervidda. Norges landbrukshøgskole, Institutt for biologi og naturforvaltning. Master thesis. 49pp. (In Norwegian).

41 Gjøstein G, Hauge TA. 1994. Vandring hjå allopatrisk aure, Salmo trutta L. i ulikt tette bestandar, eit radiotelemetristudium i tre vatn på Hardangervidda. Norges landbrukshøgskole, Institutt for biologi og naturforvaltning. Master thesis. 32pp. (In Norwegian).

42 Gulbrandsen TR, Johannessen M, Kildal T, Kjellsen A, Kulsvehagen E. 1986. Forsuringssituasjonen på Hardangervidda - kjemisk vannkvalitet og fiskestatus 1983-1985. Fylkesmannen i Telemark, miljøvernavdelingen. Rapport nr. 2/ 86. 35pp. (In Norwegian).

43 Halvorsen G. 1973. Crustacea from the High Mountain Area Hardangervidda, South Norway. Rapport fra Høyfjellsøkologisk Forskningssenter, Finse, Norge. 1973 (3). 17pp.

44 Hansen H, Garnås E. 1987. Fiskeribiologiske undersøkelser i Nedre Hein, Halnefjorden og Veslekrækkja, 1986. Fylkesmannen i Buskerud, miljøvernavdelingen. Rapport nr. 8-1987. 41pp. (In Norwegian).

45 Ingebrigtsen S, Kambestad O. 1990. Struktur, dynamikk og habitatbruk for bestanden av aure, Salmo trutta L., i Krokavatn på Hardangervidda. Norges landbrukshøgskole, Institutt for biologi og naturforvaltning. Master thesis. 46pp. (In Norwegian).

46 Jensen JW. 1976. Fisket i en del av elvene og vatnene som berøres av Eidfjord-Nord utbyggingen. Det Kongelige Norske Videnskabers Selskab, Museet, Universitetet i Trondheim. Rapport, Zoologisk serie 1975-15. 37pp. (In Norwegian).

47 Kildal T, Johannessen M. 1983. Fiskeribiologiske undersøkingar i Mårvatn og Kalhovdmagasinet 1982. Fylkesmannen i Telemark, miljøvernavdelingen. Rapport nr. 1-1983. 34pp. (In Norwegian).

48 Kildal T, Kaasa H. 1973. Rapport fra prøvefisket i Briskevatn, Mellomhølen og Mørevatn. Rapport. 28pp. (In Norwegian).

49 Kildal T, Kaasa H. 1975. Rapport fra prøvefisket i Honserud, Vollevatn og Tosketjønn. Rapport. 33pp. (In Norwegian).

50 Kildal T. 1980. Fiskeribiologiske undersøkelser i Kvenna 1978. Fiskerikonsulenten i Øst-Norge. Rapport. 41pp. (In Norwegian).

51 Kildal T. 1981. Fiskeribiologiske undersøkelser i Skvettavassdraget 1980. Fiskerikonsulenten i Øst-Norge. Rapport nr. 17-1981. 33pp. (In Norwegian).

52 Kildal T. 1982a. Fiskeribiologiske undersøkelser i Kvenna og Bjønna 1978. Fiskerikonsulenten i Øst-Norge. Rapport nr. 1-1982. 45pp. (In Norwegian).

53 Kildal T. 1982b. Fiskeribiologiske undersøkelser i Kvenna 1979. Rapport frå brukerundersøkinga i Kvenna 1979. Fiskerikonsulenten i Øst-Norge. 
Rapport nr. 2-1982. 36pp. (In Norwegian).

54 Kildal T. 1985. Prøvefiske i Rauland statsallmenning. Fylkesmannen i Telemark. Rapport. (In Norwegian).

55 L’Abée-Lund JH, Sægrov H. 2017. Ørretbestanden i Vesle Vråsjøen, Vråsjøen og Store Saure I Vinje kommune. Rådgivende biologer AS, rapport 2440. 28pp. (In Norwegian).

56 Lehmann GB, Wiers T. 2004. Fiskeressursprosjektet i Hordaland: Fiskeundersøkelser i regulerte innsjøer og vassdrag i Hordaland, juli 2002 april 2003. Fylkesmannen i Hordaland, miljøvernavdelingen. Rapport nr. 1-2004. 79pp. (In Norwegian).

57 Lehmann GB, Wiers T. 2007. Prøvefiske i Langavatnet og Håvardsvatnet for AS Tyssefaldene, august 2006. LFI-Unifob. Rapport nr. $143-2007$. 34pp. (In Norwegian).

58 Lehmann GB, Wiers T. 2011. Prøvefiske i magasiner i Tyssedalsfjellene for AS Tyssefaldene, august 2010. Undersøkelser av bestandsstatus for aure. LFI Uni Miljø. Rapport nr. 193-2011. 35pp. (In Norwegian).

59 Lehmann GB, Wiers T. 2012. Fiskeundersøkelser i reguleringsmagasin i Røldal og Suldal, august 2011. LFI Uni Miljø. Rapport nr. $204-2012$. 33pp. (In Norwegian).

60 Lehmann GB. 2008. Fiskeribiologiske undersøkelser i Skytjedalsvatnet og Skytjedalselven, Eidfjord, september 2008. LFI-Unifob. Rapport nr. 154-2008. 19pp. (In Norwegian).

61 Lehmann GB, Gabrielsen S-E, Wiers T, Sandven OR. 2008. Fiskeribiologiske undersøkelser i Halnefjorden, Store og Vesle Krækkja, Krækjungen, Heinungen og Øvre og Nedre Hein august 2007. LFI-Unifob. Rapport nr. 152-2008. 62pp. (In Norwegian).

62 Lunder K. 1 973. Fiskeribiologiske undersøkelser i Store Saure. Fiskerikonsulenten i Øst-Norge. Rapport. 15pp. (In Norwegian).

63 Løkensgard T, Rosseland L. 1963. Reguleringsoverføringer i Uvdalsvassdraget. Virkninger på fisket. Stensil.

64 Løkensgard T. 1958a. Songavassdraget, de fiskeribiologiske forhold og den planlagte regulerings innvirkning på fiskeforholdene. Rapport I, ekspropriasjonsskjønnet for Tokke-Vinjevassdraget. 22. jan. 1958. 27pp. (In Norwegian).

65 Løkensgard T. 1958b. Songavassdraget, de fiskeribiologiske forhold og den planlagte regulerings innvirkning på fiskeforholdene. Rapport VI, ekspropriasjonsskjønnet for Tokke-Vinjevassdraget. Bordalsvatnet og Margritsvatnet. 26. okt. 1958. 5pp. (In Norwegian).

66 Løkensgard T. 1975. Fiskeribiologiske undersøkelser av Hettefjorden, Eidsjåen og Kalven. Fiskerikonsulenten i Øst-Norge. Rapport, 7pp. (In Norwegian).

67 Madsen J-P. 1970-1988. Diverse fiskeriundersøkelser på Hardangervidda 1970-1988. Hordaland landbruksselskap/ Fylkesmannen i Hordaland. Diverse befaringsrapporter. (Oppbevares hos Fylkesmannen i Hordaland). (In Norwegian).

68 Meland A. 2008. Låg vasstand i Bordalsvatn sumaren 2006; innverknad på vekst og kvalitet hjå aure (Salmo trutta). Universitetet for miljø- og biovitenskap, Institutt for naturforvaltning. Master thesis. 38pp. (In Norwegian).

69 Mollerud A. 1971. Rapport fra fiskevannsundersøkelsene i Skjerjavatnet, Hol, sommeren 1970. Buskerud Landbruksselskap. Rapport. 9pp. (In Norwegian).

70 Muniz IP. 1969. Rapport fra de fiskeribiologiske undersøkelser i Eidfjord statsalmenning sommeren 1968. Konsulenten for ferskvannsfisket i Vest-Norge. Rapport. 72pp. (In Norwegian).

71 Muniz IP. 1968. Rapport fra de fiskeribiologiske undersøkelser i Odda og Ullensvang statsalmenninger sommeren 1967. Konsulenten for ferskvannsfisket i Vest-Norge. Rapport. 77pp. (In Norwegian).

72 Myrvang R, Slettebø D. 2013. Historiske aurebestander (Salmo trutta) på Sentralvidda - Endringer i bestandsstruktur og livshistorietrekk som følge av endring i beskatning og variasjon i klimaforhold. Universitetet for miljø og biovitenskap, Institutt for naturforvaltning. Master thesis. 66pp. (In Norwegian).

73 Nordland J. 1981. Fiskeribiologiske undersøkingar i A/S Tyssefaldene sitt reguleringsområde. Sommaren 1980. Fiskerikonsulenten i Vest-Norge. Rapport. 24pp. (In Norwegian).

74 NOU 1974. Norges offentlige utredninger. Hardangervidda. Natur - Kulturhistorie - Samfunnsliv. Miljøverndepartementet. NOU 1974:30 B. 352pp. (In Norwegian).

75 Olsnes SH. 2001. Forvaltningsplan for fisk - Berunuten Vest. Vinje kommune. Rapport. 14pp. (In Norwegian).

76 Pedersen K, Scobie L. 1990. Dynamikk, habitatbruk og redskapsseleksjon for ørretbestanden i Kollsvatn, en innsjø på Hardangervidda. Norges landbrukshøgskole, Institutt for biologi og naturforvaltning. Master thesis. 59pp. (In Norwegian).

77 Qvenild T, Rognerud S. 2002. Fiskeundersøkelser i Kvennadalen 2000 - 2001. Rapport nr. 1 for I/S Laagefjeld, 38pp. (In Norwegian).

78 Qvenild T. 1978. Fiskeribiologiske undersøkelser Uste - Nes, Hol kommune, 1976. Fiskerikonsulenten i Øst-Norge. Rapport. 44pp. (In Norwegian).

79 Rognerud S, Fjeld E. 2014. Undersøkelser av fisk og næringsdyr i Mår og Ringedalsvatnet i forbindelse med en nedtapping og tilslamming $\mathrm{i}$ 2010-2013. NIVA Rapport L.NR. 6682-2014. 52pp. (In Norwegian).

80 Rognerud S, Qvenild T, Fjeld E. 2005. Hardangerviddaprosjektet. Resultater fra undersøkelsen i 2004. NIVA Rapport L.NR. 5025-2005. 35pp. (In Norwegian).

81 Rognerud S, Qvenild T. 2015. Klimaets betydning for årsklassestyrke og produksjon av fisk og næringsdyr i Sandvatn 2001-2014. NIVA Rapport L.NR. 6845-2015. 40pp. (In Norwegian).

82 Rognerud S, Qvenild T. 2016. Ørreten på Hardangervidda. Klimaets betydning for årsklassestyrke og produksjon av fisk og næringsdyr $\mathrm{i}$ Sandvatn 2001-2015. NIVA Rapport L.NR. 6967-2016. 39pp. (In Norwegian).

83 Rognerud S, Borgstrøm R, Qvenild T, Tysse Å. 2003. Ørreten på Hardangervidda. NIVA Rapport L.NR. 4712-2003. 68pp. (In Norwegian).

84 Saltveit SJ, Brabrand Å. 2008. Fiskeribiologiske undersøkelser i Songa og Bitdalsvatn i 2007. Lab. for ferskvannsøkologi og innlandsfiske (LFI). Rapport nr. 263. 27pp. (In Norwegian).

85 Statens forurensningstilsyn. 2001. Overvåking av langtransportert forurenset luft og nedbør. Årsrapport 2000. Statlig program for forurensningsovervåking. Rapport nr. 834-2001 (TA-1830-2001). (In Norwegian).

86 Statens forurensningstilsyn. 2006. Overvåking av langtransportert forurenset luft og nedbør. Årsrapport 2005. Statlig program for forurensningsovervåking. Rapport TA-2205-2006. (In Norwegian).

87 Simonsen TAA, Valderhaug NA. 1994. Bestandsdynamikk, habitatbruk og ernæring for aure i Litlosvatn - ein innsjø på Hardangervidda. Norges landbrukshøgskole, Institutt for biologi og naturforvaltning. Master thesis. 65pp. (In Norwegian).

88 Skjelkvåle BL, Henriksen A. 1998. Vannkjemi, forsuringsstatus og tålegrenser i nasjonalparker; Hardangervidda. NIVA Rapport L.NR. $3895-$ 1998. 48pp. (In Norwegian). 
89 Skogheim OK, Sevaldrud I, Henriksen A, Svalastog D, Hesthagen T. 1984. Vannkvalitet og fiskestatus i utvalgte områder på Hardangervidda i 1983. Direktoratet for naturforvaltning, fiskeforskningen. Rapport nr. 4-1984. 22pp. (In Norwegian).

90 Slåttum M, Takvam L. 2006. Ørretbestanden (Salmo trutta) i Krokavatn, Ullensvang statsallmenning - én vellykket årsklasse kan gi overbefolkning. Universitetet for miljø og biovitenskap, Institutt for naturforvaltning. Master thesis. 48pp. (In Norwegian).

91 Smukkestad B. 1980. Rapport fra den fiskeribiologiske undersøkelse i Skjerja i Hol kommune 13. - 14. august 1979. Vilt- og fiskestellkonsulenten i Buskerud. Rapport. 12pp. (In Norwegian).

92 Solhøi H. 1993. Rapport fra prøvefiske i Songa 1986 og 1992. Fylkesmannen i Telemark, miljøvernavdelingen. Rapport nr. 5-1993. 24pp. (In Norwegian).

93 Solhøi H. 1997. Fiskeressurser i regulerte vassdrag i Telemark (Bordalsvatn). Fagrapport 1996. Fylkesmannen i Telemark, miljøvernavdelingen. Rapport nr. 2-1997. 28pp. (In Norwegian).

94 Solhøi H. 1999. Fiskeressurser i regulerte vassdrag i Telemark (Våmarvatn). Fagrapport 1998. Fylkesmannen i Telemark, miljøvernavdelingen. Rapport nr. 1-1999. 61pp. (In Norwegian).

95 Sømme ID. 1931. Nærings- og gytevandring hos ørreten på Hardangervidda. Norges Jæger- og Fiskerforenings Tidsskrift: 381 - 402. (In Norwegian).

96 Sømme S. 1934. Contributions to the biology of Norwegian fish food animals I. Lepiduruas arcticus Pallas 1793. Avhandlinger utgitt av det Norske Videnskaps Akademi i Oslo. I. Matem.-Naturvid. Klasse 1934. No 6: 1-36.

97 Sømme S. 1935. Innberetning om fiskeriundersøkelser ved Vikstul. Stangfiskeren (Oslo sportsfiskeres årbok 1935): 5 - 19. (In Norwegian).

99 Sømme S. 1958. Bordalsvatnet og Margritvatnene. Rapport VI, ekspropriasjonsskjønnet Tokke-Vinjevassdraget. Stensil. 5pp. (In Norwegian).

100 Tormodsgard L, Gustavsen PØ. 2013. Prøvefiske i Songavatn 2012. Naturpartner og Gustavsen Naturanalyser. Rapport GN 1-2013. 21pp. (In Norwegian).

101 Tysse Å, Elnan G. 2002. Fiskeundersøkingar i Skaupsjøen. Notat. (In Norwegian).

102 Tysse A, Garnås E. 1990. Fiskeribiologisk undersøkjing i Langesjøen og Bjornesfjorden, Nore og Uvdal kommune 1989. Fylkesmannen i Buskerud, miljøvernavdelingen. Rapport nr. 11-1990, 48pp. (In Norwegian).

103 Tysse Å, Garnås E. 1991. Fiskeribiologiske undersøkjingar i Ossjøen, Gvonnestøltjørni og Øvre Svangtjørn i Hol kommune 1990. Fylkesmannen i Buskerud, miljøvernavdelingen. Rapport nr. 12-1991. 38pp. (In Norwegian).

104 Tysse Å, Garnås E. 1992. Fiskeribiologiske undersøkjingar i Sønstevatn, Damtjørn og Vikvatn i Nore og Uvdal kommune 1991. Fylkesmannen i Buskerud, miljøvernavdelingen. Rapport nr. 23-1992. 43pp. (In Norwegian).

105 Tysse Å, Garnås E. 1994. Fiskeribiologiske undersøkjingar i Halne, Hein- og Krækkjavassdraget i Hol og Nore og Uvdal kommuner $1992 / 93$. Fylkesmannen i Buskerud, miljøvernavdelingen. Rapport nr. 16-1994. 33pp. (In Norwegian).

106 Tysse Å, Garnås E. 1995. Kalking i Buskerud 1995-1998. Fylkesmannen i Buskerud, miljøvernavdelingen. Rapport nr. 11-1996. (In Norwegian).

107 Tysse A.. 1996. Prikkauren i Svartavatnet og Svartavasstørni. Vasskvalitet, kalking og biologi. Notat. 29pp. (In Norwegian).

108 Tysse Å. 1997. Prøvefiske i Tinnhølen, Eidfjord kommune 1995/ 96. Notat. 9pp. (In Norwegian).

109 Tysse Å. 2001. Prøvefiske i Finnsbergvatnet 1999. Notat. 4pp. (In Norwegian).

110 Tysse Å. 2001. Prøvefiske i Langvatnet 1999, Eidfjord kommune. Notat. 1p. (In Norwegian).

111 Tysse Å. 2002. Undersøkjingar i Drageidfjorden 2002. Notat. 8pp. (In Norwegian).

112 Vasshaug Ø. 1970. Fiskeribiologiske undersøkelser 1967-69. Fiskerikonsulenten for Vest-Norge. Rapport. 67pp. (In Norwegian).

113 Vasshaug Ø, Waatevik E. 1976. A/S Tyssefallene - NVE og Statskraftverkene. Fiskeribiologiske reguleringsundersøkelser i Tyssovassdraget, Odda og Ullensvang kommuner. Fiskerikonsulenten i Vest-Norge, rapport. 20pp. (In Norwegian).

114 Walseng B, Halvorsen G, Schartau AKL. 1994. Ferskvannsbiologiske undersøkelser i Kvenna, 1978. NINA Oppdragsmelding nr. 321-1994. 33pp. (In Norwegian).

115 Walseng B, Raddum G, Saksgård R, Schartau AKL. 1996. Ferskvannsbiologiske undersøkelser i Kvenna 1995, med fokus på indikatorarter som redskap i forsuringsovervåkingen. NINA Oppdragsmelding nr. 433-1996. 36pp. (In Norwegian).

116 Wiers T, Hylland S. 2002. Prøvefiske i Ullensvang, Hardangervidda 2001. Langavatnet, Vasslivatnet, Reinavatnet, Busetevatnet, Vetlavatnet og Vatnasetvatnet. Naturoppdrag. Rapport nr. 35-2002. 30pp. (In Norwegian).

117 Wiers T, Hylland S. 2001. Prøvefiske i Ullensvang, Hardangervidda 2000. Veivatn, Bersarvikvatnet, Holmavatnet, Austmannavatnet, Hanasteinsvatnet, Tresnutevatnet og Skinnhovdavatnet. Naturoppdrag. Rapport nr. 32-2001. 42pp. (In Norwegian). 